\title{
NO ERA SOLO CUESTIÓN DE RISA: El teatro de H. C. Andersen
}

\author{
Klaus P. Mortensen \\ Society for Danish Language and Literature \\ Traducción de F. Nassim Bravo Jordán \\ Notas de Klaus P. Mortensen y Mads Sohl Jessen
}

\begin{abstract}
Resumen
Hans Christian Andersen es probablemente el escritor más reconocido de Dinamarca. Su fama se debe, de forma principal, a sus cuentos de hadas, los cuales han sido traducidos a incontables idiomas. Sin embargo, la producción dramática de Andersen ha permanecido en una relativa oscuridad. En el presente artículo se ofrece una recorrido por la carrera dramática de H. C. Andersen, destacando los puntos más importantes de algunas de sus piezas teatrales.
\end{abstract}

Palabras clave: Andersen, teatro, drama, comedia, Edad de Oro de Dinamarca.

\section{Abstract}

Hans Christian Andersen is probably the most famous writer from Denmark. He owes this renown mostly to his beautiful fairytales, most of which have been translated into countless languages. His dramatic authorship, however, has remained in obscurity for a long time. In the following piece I offer an overview of Andersen's career as a playwright, highlighting the most important features of some of his plays.

Keywords: Andersen, theater, drama, comedy, Golden Age Denmark.

En el comienzo estaba el teatro.

No es ninguna novedad afirmar que el teatro estaba cerca del corazón de H. C. Andersen. Pero tampoco es ningún misterio que la posteridad ha juzgado con dureza su producción dramática. Es verdad, Andersen nunca 
fue un gran dramaturgo y llegó a escribir dramas malos y mediocres. No obstante, también produjo, por ejemplo, cuentos y poemas malos. Además, escribió obras teatrales que no solo estaban a la altura de las piezas de otros autores de la época, sino que también —y esto es lo importante- estaban al nivel de sus propias obras maestras. En efecto, si empleáramos como criterio los alrededor de veinticinco cuentos de hadas, el Libro de imágenes sin imágenes [Billedbog uden Billeder] y En Suecia [I Sverrig], escritos que elevaron a Andersen a la esfera de los genios, no quedaría en su obra gran cosa que mereciera nuestra atención. En este sentido, H. C. Andersen era su propio crítico más riguroso. Ahora bien, sería absurdo establecer semejante criterio, a menos que el objetivo fuera vaciar a la literatura danesa de la mayoría de sus muchas obras meritorias.

La obra de H. C. Andersen es una de las más ricas y notables tanto en la literatura danesa como en la europea. Lo es, sobre todo, en virtud de su diversidad de expresiones, temas y figuras, por su gusto permanente por la experimentación, por su búsqueda incansable y curiosa. Las obras de teatro son una parte integral de esta obra amplísima. Si uno pretende leer a Andersen con provecho, es preciso librarse de todo juicio y prejuicio (incluyendo aquellos de sus contemporáneos, los cuales no terminan por desaparecer), y leer los textos y obras particulares como si fuéramos partícipes de un gran universo poético. Los escritos de Andersen lucen mejor cuando se leen en armonía los unos con los otros. Estos nacieron en un laboratorio artístico en el que se ensayaron — casi nunca de modo sistemático, casi siempre de forma intuitiva y espontánea- incontables posibilidades. El ensayo podía dar como resultado algo terriblemente malo, pero también cosas muy buenas.

Mientras que la mayoría de los escritores se especializan y mantienen en uno o dos géneros, H. C. Andersen probó suerte con todos, y lo hizo no de forma excluyente, sino ampliando en gran medida los imperativos artísticos. En consecuencia, no se debe perder la perspectiva debido a las categorías convencionales con las que la crítica literaria organiza las obras de Andersen y de otros autores. Y es que cuando una obra literaria explora inquietamente los fenómenos del mundo y aquello que entraña el ámbito de lo humano, la forma se convierte en portadora de temas existenciales, y en muchas ocasiones choca con las fronteras convencionales entre géneros, a veces llegando a atravesarlas. Si Andersen experimentaba a menudo con los límites entre los distintos géneros y creaba variantes o formas nuevas, esto lo hacía no porque estuviera interesado en el asunto formal en cuanto tal, sino 
porque la expresión, en su caso, estaba al servicio de la imaginación. Sus impulsos interiores exigían una forma, y esta forma a menudo se manifestaba precisamente en el traspaso y desprecio por dichas fronteras.

Si H. C. Andersen no fue un gran psicólogo, sí fue, en cambio, un magnífico fenomenólogo que se interesaba por todo aquello que se movía en el mundo exterior. Esto no significa que se deba pasar por alto lo concerniente a la ejecución artística o la psicología a menudo superficial de sus personajes. Sin embargo, lo mismo que en el caso de, por ejemplo, las novelas o las descripciones de viajes, también las obras de teatro deberían considerarse como formas que en buena medida son determinadas por los conflictos que ellas mismas describen. La imperfección técnica no equivale necesariamente a un talento deficiente, sino que es con frecuencia el resultado de la preeminencia que se le da a lo existencial. H. C. Andersen siempre estaba buscando la forma correcta, no como algo ya disponible, sino como una posibilidad depositada en el argumento mismo de la obra. $\mathrm{Y}$ esta forma posible se manifestaba frecuentemente como algo roto o inconsistente desde la sola perspectiva de las convenciones estéticas.

El poeta con el que nos enfrentamos en los dramas de Andersen no es diferente al autor que escribió cuentos de hadas, relatos, poemas, novelas y descripciones de viaje. Aquí, además, lo fantástico florece al lado de lo realista. El humor y la seriedad llegan a identificarse como medios para conocer la condición y la convivencia humana. Lo mismo encontramos ahí ingenuidad que profundidad interior, amor que odio y maldad; hallamos vulnerabilidad, indigencia y desesperación, pero también cariño, bondad, fe y esperanza. Sobre todo, descubrimos todas las indeterminadas formas intermedias que residen bajo el signo de la duda y la incertidumbre. El compromiso de H. C. Andersen con los niños no era el resultado —algo que él mismo señaló a modo de conjuro en diversas ocasiones- de un temperamento infantil, sino de un hombre que desde hace mucho había caído del estado de inocencia infantil.

H. C. Andersen es un hombre de impulsos y formas precisas. Por consiguiente, en los grandes géneros como la novela o el drama, lo fascinante funciona como un enclave dentro de una forma mayor. Todo se relaciona con una base distinta y ya esbozada. Para Andersen, la expresión siempre tiene un peso mayor que las reglas formales del juego, incluyendo la ortografía. En este sentido, Andersen es tan insolente como Hans el Patán. Si lo leemos partiendo de estas premisas un poco arbitrarias, el teatro de H. C. Andersen nos ofrece magníficas - y a veces inquietantes - lecturas. 
En El cuento de hadas de mi vida [Mit Livs Eventyr], H. C. Andersen cuenta que cuando era un niño pequeño, sus padres lo llevaron al Teatro de Odense. No tardó en quedar prendado por el maravilloso mundo de ilusiones:

Entretanto, el teatro se convirtió rápidamente en mi lugar preferido. Sin embargo, en invierno solo podía visitarlo una vez, de modo que trabé amistad con el encargado de las carteleras, Peter Juncker, quien me regalaba la cartelera diaria a cambio de que guardase en mi habitación algunos de sus carteles, tarea que cumplí a conciencia. Si no podía asistir al teatro, me sentaba en un rincón de mi casa con alguna cartelera y, basándome en el nombre de la pieza y en sus personajes, me imaginaba actuando en una comedia. Esta fue, sin darme cuenta, mi primera obra poética. ${ }^{1}$

Pronto comenzó a hacer sus propias obras. Fabricaba marionetas para tal propósito y se hacía leer o leía el mismo — una vez que aprendió a hacerlo_a Holberg y Shakespeare. De esta manera, entretenía a cualquiera con quien se encontrase con declamaciones de obras suyas o de otros autores, una práctica que, por lo demás, no abandonaría por el resto de su vida. Para el adolescente Hans Christian, este teatro hecho por él mismo se convirtió en el centro de un mundo imaginario al cual podía retirarse y en el que podía desenvolverse libremente. Era un mundo diseñado completa y literalmente por él mismo. Se adueñó soberanamente de todas las funciones: era director, director de escena, decorador, el encargado del vestuario, actor, etcétera. Era también el dramaturgo.

Cuando, después de la muerte del padre, su madre volvió a casarse en 1816, su padrastro decidió prudentemente no intervenir en el teatro total de este singular muchacho. La madre, en cambio, veía el asunto desde una perspectiva un poco diferente:

Así, pues, vivía para mi escenario en miniatura y mi teatro de marionetas; mi mayor dicha consistía en reunir trapos de una gran variedad de colores, lo cuales cortaba y cosía para convertirlos en disfraces. Mi madre juzgaba que esto constituía una buena práctica para que me convirtiera en sastre, pues, según ella, yo había nacido para tal oficio. Yo, por mi parte, aseguraba que quería dedicarme a la comedia, algo a lo cual mi madre se oponía de la forma más categórica. ${ }^{2}$

${ }^{1}$ H. C. Andersen, “Mit Livs Eventyr”, en H.C. Andersens samlede værker 1-18, ed. por Klaus P. Mortensen, Copenhague: Det Danske Sprog- og Litteraturselskab, 2003-2077, vol. 17, p. 22.

2 Andersen, "Mit Livs Eventyr", p. 28. 
Como se sabe bien, la sensatez materna terminaría por doblegarse ante el imprudente y extravagante proyecto de un decidido Hans Christian de marcharse a Copenhague para probar suerte en el teatro. Ahora bien, aunque el sueño de hacer carrera en alguno de los tres artes del Teatro Real —ópera, ballet y drama- naufragó después de tres breves años en el océano de la sociedad de Copenhague, en cambio logró sobrevivir la otra faceta del universo de este muchacho loco por el teatro: el papel de dramaturgo. En el periodo entre el verano de 1821 y el verano de 1822 , durante el cual tuvo lugar su caída más dura y en el que un Hans Christian de 16 y 17 años se perdía cada vez más en sus juegos pueriles con el teatro de marionetas, escribió tres dramas completos, todos ellos basados en sus ávidas y diversas lecturas. En primer lugar, la tragedia romántica de horror La capilla del bosque [Skovcappelet, junio de 1821], basada en la trama de un relato alemán, traducido de forma anónima, con el mismo título y publicado en la revista Brevduen (nos. 19-20, 1819). Después, Los bandidos de Vissenberg en Fionia. Un poema dramático [Røverne $i$ Vissenberg $i$ Fyen. Et dramatisk Digt], inspirado en una leyenda de las Leyendas populares danesas [Danske Folkesagn] de J. M. Thiele (segunda colección, 1819) y enviado de forma anónima al Teatro Real en marzo de 1822 (un extracto de esta obra se publicó en la revista Harpen el 9 de agosto de 1822). Y, por último, la tragedia El Sol de los elfos [Alfsol], basada en el relato nórdico de 1781 de P. F. Suhms con el mismo título; Andersen también la envió al Teatro Real. La primera obra fue archivada, aunque el manuscrito ha sobrevivido; las otras dos fueron rechazadas. Con razón. Fueron y siguen siendo ensayos de escritura compuestos apresuradamente a partir de toda clase de material literario y sin ningún tipo de cohesión. Sin embargo, no son del todo malas. Si se considera, además, que fueron escritas por un adolescente prácticamente autodidacta, resultan incluso notables. Personas perspicaces y clarividentes — con Knud Lyne Rahbek y Jonas Collin ${ }^{3}$ a la cabeza - se encargaron de garantizarle a este singular joven una educación adecuada inscribiéndolo en el liceo.

De Los bandidos únicamente se conserva el extracto publicado en Harpen, mientras que El Sol de los elfos fue incluido en Ungdoms-Forsøg,

${ }^{3}$ Knud Lyne Rahbek (1760-1830), crítico literario. Junto con su esposa, Kamma Rahbek (1775-1830), había hecho de su casa uno de los salones literarios más importantes en Dinamarca durante las primeras décadas del siglo XIX. Jonas Collin (1776-1861), abogado y miembro de la dirección del Teatro Real. Fue mecenas de varios artistas y escritores daneses, incluido H. C. Andersen. 
publicado en agosto o septiembre de 1822, con H. C. Andersen como editor. De los registros que se conservan, se puede observar que el volumen tuvo al menos 24 subscriptores; entre estos, el rey adquirió 6 ejemplares. Pero las ventas fueron malas. Esto nos habla de la tenacidad de H. C. Andersen: el hecho de que, después de tres dolorosas derrotas en fila, insistiera a pesar de todo en el género dramático. Lo cierto es que transcurrieron siete años completos antes de que, tras aprobar su examen final en el liceo, hiciera un nuevo intento, en 1828, con Amor en la Torre de san Nicolás o lo que diga el público. Vodevil heroico en un acto [Kjerlighed paa Nicolai Taarn eller Hvad siger Parterret. Heroisk Vaudeville i 1 Act]. Por lo demás, esta obra tuvo un éxito moderado. Su aprobación fue decente y tuvo tres representaciones con casa llena. Nada mal para un debutante.

Los críticos, que en su mayor parte eran benévolos —aunque, fieles a su costumbre, también se mostraban un poco condescendientes con el joven y nunca resignado poeta Andersen-, consideraron al vodevil como una broma trivial. La obra, por su parte, está cargada con la misma insolencia, malicia y forzada ironía de su primer libro, El viaje a pie [Fodreise], en el que nada escapa a los claroscuros de la ironía. Pero entre las ambiciones de la pieza está también la de hacerse notar mediante un ajuste de cuentas con las formas literarias caducas. La broma no era una mera broma. Por lo demás, esto era rara vez el caso con Andersen.

La intriga principal de esta pequeña obra era bien conocida gracias a Holberg ${ }^{4}$, en general, a la tradición cómica. El padre (Ole) desea casar a su hija (Ellen) con un conocido suyo (su colega vigilante, Peer Hansen), pero la hija ama a un joven (el sastre Søren Pind), lo cual conduce, en un pasaje particularmente sentimental, a la conmovedora exclamación de Ellen: “¡Pind, mi Pind!” A través de grandes dificultades se llega al desenlace: todos los personajes, junto con sus proyectos, quedan expuestos al ridículo. Aunque la tradición exigiría que los dos jóvenes amantes se unieran antes de que cayera el telón, este vodevil tiene un final abierto. Después de una lucha indecisa entre vigilantes y sastres, en la cual Søren Pind se revela como un sastre genuino, el padre, Ole, anuncia que es deber del público resolver la cuestión. Si el público aplaude, como estaba escrito que ocurriera -y

4 Ludvig Holberg (1864-1754), dramaturgo danés. Su obra es considerada paradigmática dentro de la literatura danesa.

${ }^{5}$ H. C. Andersen, "Kjærlighed paa Nicolai Taarn eller Hvad siger Parterret", en H.C. Andersens samlede værker 1-18, ed. por Klaus P. Mortensen, Copenhague: Det Danske Sprog- og Litteraturselskab, 2003-2077, vol. 10, p. 103. 
como, de forma interesante, indica el título de la obra-, Ole aparece y los dos jóvenes pueden unirse. Si no aplaude, Ellen se queda con Peer. El último parlamento de Pind sintetiza lo espinoso de la elección del público:

Al fin y al cabo, en el vodevil

Sale uno a parlotear

Lo que dispuso el escritor.

Uno se contenta con aplaudir,

Pero aquí no se trata solo del autor,

Sino de una pareja unida por el amor.

¿Qué me dices, público?

¿Me concederás a Ellen? ${ }^{6}$

Por otra parte, este juego de ficción dentro de la ficción no es más que el último eslabón de de una vasta parodia del drama burgués. Cuando Ellen se enfrenta a los proyectos de su padre con respecto a su futuro, exclama:

Un negro demonio la escena atraviesa,

Llevando en su cabellera los resortes del hado.

Me amenaza y alza su huesuda mano

Contra mis flores, de las cuales destruye la mejor.

(...)

¡Así que esto debe ser una tragedia!

¡Así lo quiere la tradición! ${ }^{7}$

Los personajes son partícipes en el curso de los acontecimientos y, al mismo tiempo, no pueden hacer nada a causa de su conciencia de las leyes inquebrantables a las que están sometidos, no en virtud del destino, sino de las convenciones del género. Por ejemplo, Maren consuela a Ellen asegurándole que todo va a terminar felizmente y le aconseja aguantar hasta la última escena, a lo cual Ellen replica:

Tienes razón, sí, en Kotzebue y en Schröder,

$\mathrm{Y}$ en las comedias y dramas burgueses.

¡Pero aquí se busca más que eso!

(...)

¡La locura me amenaza, quizá un veneno o puñal!

Tales son los manjares que ansía nuestra gente. ${ }^{8}$

${ }^{6}$ Andersen, “Kjærlighed paa Nicolai Taarn”, p. 112.

7 Andersen, "Kjærlighed paa Nicolai Taarn”, p. 77.

${ }^{8}$ Andersen, “Kjærlighed paa Nicolai Taarn”, p. 80. 
Esta clase de violación del contrato tácito con el público con respecto a la cuestión de tomarse en serio la trama y los personajes no era algo nuevo. Ludvig Holberg lo había hecho en un pasaje de su Ulises de Ítaca [Ulysses von Itachia, 1724], y Johan Herman Wessel ${ }^{9}$ había intentado algo parecido, aunque en una escala mucho mayor, en Amor sin medias [Kizrlighed uden Strømper, 1772], obra que fue una de las más importantes fuentes de inspiración para nuestro joven dramaturgo. En realidad, tampoco sentía empacho en tomar partes de obras como La colombina como paloma [Columbine som Due, 1820] de Simon Meisling, ${ }^{10} \mathrm{y}$ El desesperado en la Torre Redonda [Den Fortvivlede paa Runde-Taarn, 1825] y El sastre grandilocuente [Den bøjtravende Skræedder, 1827] de C. N. Rosenkilde. ${ }^{11}$ Pero en Andersen este juego con el contrato con el público es total. De esta manera, el más mínimo enredo se convierte en un pretexto para burlarse de las convenciones literarias y del espíritu burgués. Exactamente lo mismo que en El viaje a pie. Para el joven H. C. Andersen, lo realmente importante no es el drama [skuespillet] como un desarrollo articulado, sino el juego [spillet] mismo, es decir, el juego lingüístico momentáneo — casi anárquico- con las palabras y representaciones con las cuales la gente se rige en el juego convencional de la sociedad.

Detrás del juego un poco forzado y de la ligereza, existe una noción seria - aunque imprecisamente heterodoxa- de acuerdo con la cual el juego del destino no es simplemente algo a lo que el ser humano se somete de forma involuntaria. El destino es en buena medida el resultado de las voluntades humanas en el juego social y cultural que lo envuelve todo. Esto lo sabía H. C. Andersen gracias a sus propias y duras experiencias. El drama pone a la vista — precisamente en virtud de su carácter de juego- ese otro juego. Detrás de todos los rodeos teatrales, uno puede vislumbrar que eso que aquí se plasma a través de la distancia lingüística y reflexionada del juego, ha adquirido un gran poder.

\section{II}

Suponer, como suele hacerse, que el amor de H. C. Andersen por el teatro fue, en su mayor parte, un amor desdichado, no es del todo correcto; semejante suposición es demasiado estrecha de miras. De acuerdo con Andersen, en

\footnotetext{
9 Johan Herman Wessel (1742-1785), poeta y dramaturgo noruego.

${ }^{10}$ Simon Meisling (1787-1856), filólogo y traductor danés.

${ }^{11}$ Christian Niemann Rosenkilde (1786-1861), dramaturgo danés.
} 
el teatro suele ocurrir - entre muchas otras cosas - que los triunfos se mezclan con las derrotas. Y tuvo más de las segundas que de los primeros. En Andersen no hay verdades simples. Como escritor era tan multifacético, ambiguo y oscilante que como persona privada. En este sentido, es preciso no pasar por alto el hecho enormemente importante de que su dedicación al teatro no estaba fundada en una simple fascinación, sino también -y esto desde una época muy temprana- en una clara deliberación. Detrás de la (excesiva) sensiblería, se ocultaba un hombre práctico poseedor de una fuerza de voluntad y una capacidad de supervivencia considerables. Esta faceta realista la encontramos bajo una figura todavía inocente, aunque expresiva, en el pasaje antes citado de El cuento de hadas de mi vida, en el cual H. C. Andersen describe su primera visita al teatro: "Según mis padres, lo primero que dije al contemplar el teatro y el gran número de personas que había ahí, fue: ‘ $\mathrm{O}$ h! ¡Si tuviéramos tantos frascos de mantequilla como gente hay aquí, vaya que me daría una comilona!’”12

En esta inocente declaración se agita una conciencia prosaica e instintiva de que ahí había buenas ganancias. Si fuera dueño de la caja del teatro, atrás quedaría el pan duro y nadaría en cambio en una montaña de deliciosa mantequilla.

Cuando Hans Christian decidió viajar a Copenhague para probar suerte en el teatro, eso que a sus conocidos —y en especial a su madre-debía parecerles un simple desvarío, tenía un fundamento parecido de sobriedad. Este recién consagrado no era un soñador, sino un hombre audaz que quería alejarse a cualquier precio de la pobreza y del duro trabajo físico y sin perspectivas para ascender a un mundo diferente. Y es que Hans Christian se acercó con instinto seguro al teatro, un lugar donde era posible hacer carrera sin haber realizado estudios formales. Cuando más tarde apostó por escribir para el teatro —en 1821-1822, 1828 y los años que siguieron—, ahí no hubo tampoco manifestación alguna de un entusiasmo primitivo y febril por el teatro, sino también el presentimiento seguro de que ahí estaban las verdaderas posibilidades de ascender en el plano artístico y social.

Si era imposible convertirse en bailarín de ballet, en cantante o en actor - lo cual, como se sabe, era así para el torpe y desvencijado Hans Christian-, entonces quizá sería posible escribir alguna pieza para el Teatro Real. Y si se obtenía algún éxito, con esto se procuraría no solo fama y respeto, sino que también se aseguraría un sustento, al menos por algún tiempo. Con la primera representación de una obra, el autor obtenía unos honorarios de

${ }^{12}$ Andersen, "Mit Livs Eventyr", p. 21. 
entre 60 y 100 táleros (según la extensión de la pieza), además de la sexta parte de las entradas. Lo anterior ascendía por lo regular a una cifra de entre 80 y 100 táleros, dependiendo de si había o no casa llena. Cuando, después de su afortunado debut con El viaje a pie en enero de $1829, \mathrm{H}$. C. Andersen representó su primer vodevil el 25 de abril, es indudable que estos factores económicos tuvieron una gran importancia. Por ejemplo, fue de gran ayuda que eligiera este género ligero, con el cual Johan Ludvig Heiberg había tenido un éxito colosal en la ciudad. ${ }^{13}$ Audaz como era, claro está, no se limitó a seguir las huellas de Heiberg. También puso distancia con respecto al género favorito de Heiberg — de forma aparentemente inocente y bromista - al convertir el carácter literario del vodevil en el elemento decisivo de la obra. "Lo que diga el público", como señala abiertamente el título. ¡Para que el escritor tenga mantequilla en su pan, es preciso que aplaudan a su obra! Eso era (también) el meollo del asunto.

Es la historia de un joven que intentó con tenacidad vivir de sus escritos y que apostó por el teatro como su oficio principal. El joven, ambicioso y pobre autor escribió también una serie de obras dramáticas en el periodo anterior a su gran viaje de formación de abril de $1833 .{ }^{14}$ En total, salieron a la luz siete adaptaciones o piezas originales de muy diferente naturaleza. Sin embargo, todas ellas tienen en común el formar parte de su intento por tocar el gusto del gran público. En esto a veces corrió con suerte; a veces no.

\section{III}

Con Amor en la Torre de san Nicolás Andersen comenzaría propiamente su producción dramática, la cual, con la excepción de algunas pausas, se extendería hasta 1869. En conjunto, unas 40 obras a lo largo del mismo número de años, aunque de forma irregular. Como solía ocurrir con H. C. Andersen, estas obras se dividieron en un amplio abanico de subgéneros: comedias, vodeviles, libretos operísticos, comedias de fantasía, tragedias,

13 Johan Ludvig Heiberg (1791-1860), poeta, filósofo, dramaturgo, crítico literario y esteta danés. Desempeñó un papel decisivo en la escena artística de Copenhague, especialmente como dramaturgo y crítico literario. Introdujo con gran éxito en Dinamarca el vodevil, género que había conocido en París. En la cúspide de su carrera, Heiberg se convirtió en el juez supremo en cuestiones estéticas en el mundo cultural de Copenhague, una posición que lo llevaría a enemistarse con otras grandes figuras literarias como Andersen, Kierkegaard y Oehlenschläger.

${ }^{14}$ En 1833, Andersen recibió un apoyo económico por parte del rey para realizar un viaje a través de Europa, del cual regresaría en 1834. 
dramas urbanos, dramas de situación, prólogos, collages, dramas de lectura. Manejaba distintos temas tomados de su propia época o de la historia, de leyendas o de la literatura. En la mayoría de los casos, una historia de amor constituía el hilo conductor de la acción.

Era frecuente que la aceptación o escenificación de una pieza - $\mathrm{O}$, en varios casos, el trabajo de musicalización del compositor- retrasara la representación por medio año o un año entero; a veces incluso por varios años. Esto significa que si se desea seguir de cerca los procesos poéticos, la cronología según el orden de las representaciones puede distorsionar la imagen de aquello en lo que H. C. Andersen estaba trabajando en realidad en un momento dado.

También es importante tomar en consideración las producciones dramáticas tempranas. Si las obras que H. C. Andersen escribió o adaptó antes de su gran viaje de formación las nombramos de acuerdo al orden en que fueron redactadas, obtendremos una imagen distinta del primer intento de Andersen por conquistar el Teatro Real que si seguimos la cronología según las representaciones. Con una sola excepción, todas las obras fueron representadas en el Teatro Real, aunque en el transcurso de un periodo mucho más prolongado que el que tenía proyectado el autor. Lo anterior significa, por ejemplo, que dos piezas importantes que fueron escritas antes del viaje de formación, no se representaron sino hasta después del regreso de Andersen en el verano de 1834, como se muestra a continuación:

- La ópera fantástica El cuervo o la prueba del hermano [Ravnen eller Broderprøven], "basada en el cuento tragicómico de Gozzi", se entregó en mayo de 1830 y se representó el 29 de octubre de 1832.

- La opereta La novia de Lammermoor [Bruden fra Lammermoor], basada en la novela de Walter Scott del mismo nombre, fue terminada el 20 de febrero de 1831 y se representó el 5 de mayo de 1832.

- El vodevil El barco [Skibet], adaptación y traducción de La Quarantaine de Eugène Scribe y Mazères, fue admitido alrededor del 20 de agosto y representado el 5 de octubre de 1831.

- La opereta Elfestín de Kenilworth [Festen paa Kenilworth], inspirada en la novela Kenilworth de Walter Scott, la terminó en junio de 1832 y fue representada por primera vez el 6 de enero de 1836.

- La opereta El dos de abril [Den anden April] se entregó en septiembre de 1832, pero nunca fue representada.

- El drama La reina de 16 años [Dronningen paa 16 Aar], traducida y 
adaptada a partir de La Reine de seize ans de Jean François Alfred Bayard, se representó por primera vez el 29 de marzo de 1833.

- El vodevil doble Los españoles en Odense [Spanierne i Odense] y Veinticinco años después [Femogtyve Aar derefter], se entregó en marzo de 1833, se revisó en el verano de 1835, se admitió en noviembre de 1835 y se representó por primera vez el 16 de abril de 1836.

Las piezas se encuentran en tres grupos principales, mismos que aparecen en toda la producción de Andersen, aunque con diferente peso: traducciones/adaptaciones, piezas basadas en obras literarias (como los tres trabajos del periodo 1821-1822) y, por último, obras donde la trama es (en términos generales) original.

Sería exagerado hablar de una estrategia integral en este primer avance. En este punto, H. C. Andersen trabaja en buena medida de forma impulsiva y solo en pocas ocasiones de acuerdo con planes concretos y a largo plazo. Pese a ello, hay algunos intereses principales que lo conducen, algo que puede verse claramente. La comedia o el vodevil son los géneros preferidos, indudablemente debido a que eran del gusto del público, pero también porque se acomodaban bien al desarrollado sentido del humor de Andersen, así como a su afición por la sátira y la ironía. Mientras que estas piezas ligeras emplean intrigas simples y pocos personajes trazados de forma sencilla, las dos operetas largas y serias basadas en Scott flirtean con lo trágico e introducen tramas y personajes considerablemente más complicados. Estas dos obras representan la otra línea principal, más seria, de la producción dramática de Andersen.

Pero a pesar de esta posición fundamental, la mayoría de las piezas se caracterizan por la interacción entre el discurso y las canciones. La inclinación hacia lo musical se debía al reconocimiento de su popularidad entre la gente, pero también al gran interés musical de H. C. Andersen. Así, el gran número de canciones incluidas en las obras le permitieron demostrar su singular talento como creador de versos. En términos generales, tenía buen olfato para la escena. Sus obras - con la excepción de un par de casos notables - no eran material de lectura, sino que habían diseñadas con una conciencia muy clara de las exigencias y posibilidades del teatro. En consecuencia, a fin de apreciar realmente las obras teatrales de Andersen, el lector no debería leerlas como se lee una novela o un cuento de hadas. Sería preciso representarlas, por así decirlo, en la escena interior de cada uno. 
En El cuervo o la prueba del hermano, basada en el cuento cómico de Carlo Gozzi, ${ }^{15}$ El cuervo - traducido y editado por Simon Meisling en las Farsas italianas de Carlo Gozzi (1825) —, se emplea toda la parafernalia del cuento de hadas: gnomos, elfos, sílfides, salamandras, vampiros, sirenas y un silfo, además de eunucos, cortesanos, guerreros, marineros y algo a lo que se denomina "el pueblo". En semejante juego multicolor se despliega la trama, la cual no es menos abigarrada. La magia es la fuente y el hilo conductor de la intriga: el amor de dos hermanos es sometido a una dura prueba. Al final, sin embargo, se rompe el hechizo gracias a su nobleza intrínseca. La trama principal se halla cargada de un pathos impetuoso que no armoniza del todo con el asunto de la hechicería. El énfasis de H. C. Andersen no está puesto en la credibilidad psicológica, mucho menos en la profundidad de los caracteres, sino en la extravagancia de la trama y en todos los efectos teatrales, incluyendo sus muchas canciones, coros y recitativos. De forma un poco parecida a lo que ocurre en La capilla del bosque, Andersen sucumbe a la tentación de amontonar pasiones y efectos, sin un manejo preciso de las bromas. Le cuesta trabajo controlar sus ocurrencias. Por fortuna, esta trama ampulosa y poco refinada es aderezada de vez en cuando con una serie de elementos humorísticos y populares, con ese tono bromista que tanto éxito había logrado en su primer vodevil. Aquí el poeta se siente a sus anchas.

Mucho más lograda es su dramatización de Walter Scott, ${ }^{16}$ la pieza trágica La novia de Lammermoor. El modelo, la novela The Bride of Lammermoor, es seguido con precisión, y su realismo le impone de antemano un freno a las ocurrencias. H. C. Andersen es más económico con sus recursos y con los elementos de la trama, mientras que el ritmo de la pieza garantiza una constante tensión. También es consciente de cuál era su objetivo, el cual se expone en el prólogo incluido en la versión impresa. Comienza citando al mismísimo Oehlenschläger, ${ }^{17}$ en cuya opinión la diferencia entre la poesía épica y dramática es tan grande que aquel que recompone un original, puede con derecho considerar la nueva obra como creación suya. El ejemplo que propone Oehlenschläger era ni más ni menos que Shakespeare. De esta

${ }^{15}$ Carlo Gozzi (1720-1806), poeta y dramaturgo italiano.

${ }^{16}$ Walter Scott (1771-1832), escritor escocés. Scott, a quien se atribuye la creación de la novela histórica, ejerció una gran influencia en Europa durante el siglo XIX.

${ }^{17}$ Adam Oehlenschläger (1779-1850), contemporáneo de Andersen, fue el principal exponente del Romanticismo danés. 
manera, el poeta Andersen, quien no carecía enteramente de talento para la estrategia, procedió a realizar una maniobra semejante de autoridad al señalar por su cuenta que "Oeblenschläger ha creado su glorioso Aladdin basándose en un conocido relato". Así obtenía una coartada y establecía la medida para su propia aportación. Con toda humildad. "He intentado incluir la totalidad de la novela en este breve drama, aprovechando todo aquello que, a mi parecer, era posible aprovechar, y omitiendo tan solo aquellos episodios de los que se podía prescindir sin menoscabo para el conjunto". ${ }^{18}$

Este prólogo expone los puntos principales detrás de las muchas adaptaciones que H. C. Andersen realizó a través de los años. Dichas adaptaciones nos hablan de Andersen, el hombre de teatro, y de su gusto y orientación literaria como poeta; pero, sobre todo, enfrentan al lector con la cuestión más complicada de todas: dónde termina el modelo y dónde comienza Andersen. No puede decirse que las adaptaciones formen parte en estricto sentido de su obra: aunque fueran redactadas por él, no habían brotado de su imaginación poética, por más que él mismo las juzgara como piezas originales en el mismo sentido de aquellas obras de Oehlenschläger y Shakespeare basadas en otros modelos literarios. Si bien la distancia con respecto a los modelos podía variar y, de este modo, también podía ser distinto el grado de aportación del autor, es preciso reconocer que, en el caso de Andersen, existía una sobrevaloración.

De forma parecida, no descubrimos mucho más de H. C. Andersen - con la excepción de su faceta como hábil traductor y adaptador- en el ligero y un poco insolente vodevil francés El barco, en el cual una viuda y su antiguo novio se encuentran atrapados en una cuarentena debido a que se sospecha equivocadamente que él es portador de una enfermedad. Este aprovecha con éxito la situación para reconquistar a su amada y ganarle la partida al favorito de ella, el santurrón mercader. Algo semejante ocurre en La reina de 16 años, la cual habla sobre la joven y testaruda, aunque inteligente, reina Cristina de Suecia. Se trata sin más de una traducción. La pieza recibió el aplauso del público, sin duda debido a que Johanne Luise Heiberg ${ }^{19}$ había representado el papel principal. Por otro lado, las

${ }^{18}$ H. C. Andersen, "Bruden fra Lammermoor", en H.C. Andersens samlede værker 1-18, ed. por Klaus P. Mortensen, Copenhague: Det Danske Sprog- og Litteraturselskab, 2003-2077, vol. 10, p. 160.

${ }^{19}$ Johanne Luise Pätges (1812-1890), la esposa de Johan Ludvig Heiberg, era la actriz principal de la escena danesa, en la que los principales dramaturgos, incluido Andersen, codiciaban tenerla en sus obras. 
adaptaciones que incluían canciones le aportaban algo al original, aunque, por regla general, la única función de las canciones era la de separar los distintos episodios de la trama. El costo de lo anterior era que a menudo se perdía elasticidad en la tensión dramática.

El conflicto en La novia de Lammermoor es clásico. Edgar se enamora de Lucie, hija del hombre del que ha jurado vengarse, Lord Ashton. Este ha expulsado al padre de Edgar del solar familiar, pero mientras que Lord Ashton posee un carácter conciliador, Lady Ashton se opone a ambos y obliga a su hija a casarse con el malvado terrateniente Bucklaw. Cuando Edgar se dispone a batirse con él en duelo, perece al caer en arenas movedizas en su camino al sitio del duelo, y Lucie muere cuando se entera de lo ocurrido. La ópera - u opereta - tuvo un buen recibimiento por parte del público en su estreno el 5 de mayo; la crítica, en cambio, no fue tan positiva. Mientras tanto, H. C. Andersen ya estaba preparando otra adaptación de Walter Scott, El festín de Kenilworth. Deseaba jugársela en grande, y la recepción del público - la cual, en la cuestión de los ingresos, era mucho más importante que una crítica malhumorada - lo convenció de que su estrategia era correcta. El texto estuvo listo apenas un mes después del estreno de Lammermoor, pero la música se retrasó hasta enero de 1836, porque Weyse, ${ }^{20}$ para desesperación de H. C. Andersen, era incapaz de terminar su trabajo y, por añadidura, había cambiado el texto mientras Andersen estaba en el extranjero, presuntamente por razones musicales. Por si esto fuera poco, el compositor metió las manos de forma importante en el final de la obra. En consecuencia, H. C. Andersen se vio obligado a suavizar el desenlace trágico del relato original de Scott, proveniente de la época de Isabel I, acerca del escéptico Leicester, quien está dividido entre sus ambiciones políticas y su amor. En la obra de Scott, Leicester pierde el control de su propia intriga, la cual termina costándole la vida a su joven esposa, Emmy (a quien había desposado secretamente), debido a las maquinaciones del malvado esbirro de Leicester. En cambio, en la versión de Andersen, ella se salva en el último momento, gracias al sentimentalismo de Weyse. El villano cae en su propia terrible trampa, precipitándose a su muerte, mientras que el escéptico Leicester se transforma en un buen

${ }^{20}$ Christoph Ernst Friedrich Weyse (1774-1842) fue el principal compositor danés durante la primera mitad del siglo XIX. Sus piezas más famosas son las musicalizaciones de las canciones e himnos de Grundtvig e Ingemann. De hecho, la música de El festín de Kenilworth fue el último trabajo dramático de Weyse. El compositor había tenido problemas con Andersen pues consideraba que el drama carecía de la suficiente tensión dramática. 
amante y esposo. El conjunto es emocionante y entretenido, pero desde una perspectiva psicológica es poco creíble. Una trivialización de la novela de Scott, la cual, a pesar de eso - ¿o gracias a eso? - obtuvo un gran aplauso por parte del público, un aplauso del que dependían tantas cosas.

El inmensamente diligente y (demasiado) eficaz H. C. Andersen alcanzó a entregar dos vodeviles conjuntos, Los españoles en Odense y Veinticinco años después, antes de viajar al sur en abril de 1833. La opinión de Heiberg era más acertada que amigable, algo que nos habla tanto de Heiberg y su sistema de géneros como de Andersen. Para Heiberg, el joven y veloz escritor era "un improvisador lírico" ${ }_{21}$ que no había comprendido la diferencia de géneros entre la ópera y el vodevil. H. C. Andersen carecía de "serenidad y sangre fría, requerimientos indispensables para aquel que desee trabajar en el teatro". ${ }^{22}$ Heiberg sabía de lo que estaba hablando.

Después de revisarlas en 1835, las dos piezas recibieron un título común, Despedidas y encuentros [Skilles og mødes]. El resultado, de hecho, no fue tan malo. La obra se basa en los propios recuerdos de Andersen. Trata acerca de un joven soldado español que, en el contexto del acantonamiento del cuerpo expedicionario español en Fionia durante las guerras napoleónicas, se enamora de una muchacha danesa y es correspondido por ella. Sin embargo, ella decide mantenerse fiel a su leal Ludvig. Veinticinco años después, vuelven a encontrarse en Dinamarca. Ahora ella es viuda y tiene una hija; él lleva consigo a su hijo. La historia de amor se repite en la segunda generación, solo que en esta ocasión hay un desenlace feliz. La recepción del público fue adversa cuando la obra se representó en 1836. Esta pequeña historia sentimental no tuvo una muy buena acogida. Después de su regreso a casa, Andersen no había entendido cabalmente hacia dónde soplaba el viento en la escena dramática, lo cual quizá no resulta demasiado impresionante si se considera que en el periodo entre 1834 y 1837 se dedicó a escribir tres novelas de gran extensión, además de comenzar a escribir algunos cuentos para niños. En este momento, los niños todavía no contaban para gran cosa.

${ }^{21}$ Johan Ludvig Heiberg, "Brev fra J. L. Heiberg til Jonas Collin, 23. November 1833 [Carta de J. L. Heiberg a Jonas Collin, 23 de noviembre de 1833]", en Breve og Aktstykker vedrørende Johan Ludvig Heiberg [Cartas y documentos relacionados con Johan Ludvig Heiberg], vols. 1-5, ed. por Martin Borup, Copenhague: Gyldendal, 1948, vol. 2, p. 180.

${ }^{22}$ Ibíd. 
En 1835, H. C. Andersen compuso una dramatización ligera, "Un soldado de verdad [En rigtig Soldat]", que no llegaría a representarse a pesar de las revisiones, pero que sería incluida más adelante en Tres piezas poéticas [Tre Digtninger] de 1838. Los otros tres trabajos de este periodo tampoco corrieron con suerte desde una perspectiva teatral. En junio de 1835, entregó la ópera breve La pequeña Kirsten [Liden Kirsten], la cual no sería puesta en escena sino hasta diez años después, en mayo de 1846, pero que, en compensación, se convertiría en un éxito duradero, en gran medida gracias a la pegajosa música de J. P. E. Hartmann.. ${ }^{23}$ La ópera, repleta de canciones populares, se desarrolla en el siglo XII. Kirsten, la hija de un terrateniente, está a punto de ingresar al claustro cuando recibe la visita de su hermano de leche, Sverkel, a quien no ha visto desde que ella era un niña y él un jovencito. Para los espectadores, todo indica que en realidad tienen una misma madre, de suerte que su relación es un amor imposible e incestuoso. Pero más adelante se revela que él ha nacido de otra madre, así que todo termina felizmente.

Un año después, en junio de 1836, entregó la comedia musical La boda de Renzo [Renzos Bryllup]. La pieza se basa en la novela de Alessandro Manzoni, ${ }^{24}$ I promessi sposi, en la que unos peligrosos bandidos amenazan la felicidad de una joven pareja. Esta pequeña ópera tendría que esperar todavía más, catorce años, antes de ser representada en 1849 con el título de La boda en el lago de Como [Bryllupet ved Como-Søen]. La tercera pieza, Una noche increíble [En utrolig Aften], un vodevil adaptado a partir del original alemán y entregado en 1836, fue sencillamente rechazado.

\section{$V I$}

Con todo, estas dificultades eran poca cosa frente al fiasco — sin duda alguna el más grande en su carrera como autor-con el que H. C. Andersen tropezó durante su gran viaje de formación. Lleno de confianza y expectativas, el 12 de septiembre de 1833 había enviado a casa la segunda y última parte de su gran poema dramático, Inés y el tritón [Agnete og Havmanden]. Sin embargo, cuando este drama, diseñado para ser leído, salió a la luz el 23 de diciembre del mismo año, la recepción fue terrible tanto en la esfera pública como en la privada. H. C. Andersen cayó en una profunda crisis que, de paso, amenazó con arruinar su viaje. Había puesto sus esperanzas

${ }^{23}$ Johan Peter Emilius Hartmann (1805-1900), compositor danés.

${ }^{24}$ Alessandro Manzoni (1785-1873), poeta y novelista italiano. 
en que con esta obra, en la cual había trabajado de forma intensa y eufórica durante la primera parte de su viaje, podría darle a su producción literaria una nueva y decisiva orientación con la que lograría silenciar a sus críticos en casa. Inés le permitiría, de una vez por todas, dejar de depender de todas esas consideraciones no solicitadas. Ya en una carta a Christian Voigt del 26 de junio, anticipa con alegría: "Esta obra cerrará la boca a muchos". ${ }^{25}$

El resultado inmediato fue justamente lo opuesto. No obstante, si se desea comprender el motivo por el que Andersen — que, por cierto, estaba bastante acostumbrado a las críticas despiadadas- se tomó precisamente esta tan a pecho, es necesario no solo tomar en cuenta sus expectativas irreales. Y es que aquí no se trataba meramente de tener mantequilla para el pan. Inés y el tritón era el fruto de una crisis personal y literaria de la que su gran viaje debía arrancarlo. Así, Andersen se había visto obligado a explorar su propia esencia enigmática a través de este drama basado en la canción popular sobre "Inés y el tritón".

La canción, que solo se conserva en su versión tardía (de los siglos XVII y XVIII), trata sobre una muchacha cuyos anhelos están divididos en dos mundos completamente diferentes: el mundo cristiano de la tierra y el mundo pagano del mar. En la fábula, el seductor tritón arrastra consigo a Inés al fondo del mar, donde ella da a luz a su hijo. Después de siete años, al escuchar las campanas de la iglesia, ella siente nostalgia por su hogar. Regresa, pero solo para descubrir que todo ha cambiado, incluso ella misma. Muere en la playa, la frontera entre la tierra y el mar, sin haber sido capaz de elegir un mundo sobre el otro.

La crítica, que como siempre ponía énfasis en las carencias lingüísticas y técnicas de Andersen, señalaba, en términos generales, la falta de unidad y el carácter incompleto de la pieza. Pero debajo de estas objeciones formales y estéticas, había algo mucho más grave en juego, algo que no se mencionaba de forma directa en las críticas. El asunto era demasiado espinoso para la época. Lo diría el perspicaz y libre de prejuicios H. C. Ørsted, uno de los patrocinadores más leales de H. C. Andersen, en una carta privada de abril de 1834 dirigida a su joven amigo poeta. Ahí comenta lo siguiente acerca del deseo de la protagonista, Inés, por el tritón: "Esto no es sino avidez por algo que es grande en un sentido sensible (...) El poeta puede permitirse describir semejante cosa, pero también es menester que haga ver que esta atracción es una seducción, algo demoniaco. Dicho elemento demoniaco no

25 "H. C. Andersens brevveksling med Christian Voigt [Correspondencia de H. C. Andersen con Christian Voigt]”, en Anderseniana, vol. 1, no. 2, 1948, p.121. 
debe ser algo invencible para el ser humano. Es preciso representarlo como el resultado de una culpa, no como aquello a lo que se está condenado por el destino". ${ }^{26}$

La reacción del bien intencionado Ørsted arrojaba luz sobre un hecho en Inés y el tritón del que H. C. Andersen no se había percatado. Eso que él deseaba y creía haber expresado, no era lo que los lectores habían entendido. Estos juzgaron la pieza como un intento desafortunado por absolver al ser humano que se deja arrastrar por pasiones repugnantes. La figura de Inés constituía una amenaza para la decencia.

Si el gentil Ørsted y muchos otros habían sido capaces de interpretar a Inés de este modo, era porque tenían buenas razones para hacerlo, tomando en consideración la moral de la época con respecto a las cuestiones de género. Para Andersen, al igual que para Jens Baggesen, ${ }^{27}$ quien había escrito una interpretación psicológica de la fábula, "Inés de Holmegaard [Agnete fra Holmegaard, 1808]", el mundo marino no era algo sobrenatural, sino el símbolo de las profundidades de la naturaleza humana. En Baggesen —en quien se había inspirado Andersen—, se trata de una mujer que abandona a su esposo y a sus dos hijos a causa de una pasión de naturaleza erótica. En la versión de Andersen, en cambio, donde Inés es soltera y tiene un pretendiente leal, aunque insignificante, el músico Hemming, la historia es completamente distinta. Era una especie de alegoría acerca de una experiencia profundamente personal que, en cualquier caso, no era de un carácter propiamente erótico. Se trataba, a saber, del hecho de sentirse escindido entre dos mundos sociales, dos culturas. Como él mismo lo dice en el prólogo incluido en el manuscrito final, la obra habla acerca de "el deseo siempre insatisfecho del corazón y de su anhelo por un mundo nuevo y diferente". ${ }^{28} \mathrm{El}$ muchacho de pueblo había roto el vínculo con su existencia original, social y culturalmente hablando, y había ascendido a un mundo urbano en el que, por lo demás, se sentía ajeno. Andersen era un melancólico crónico.

La situación misma en la que se desarrolla la idea de Inés y el tritón es un buen ejemplo de la manera en que esta nostalgia se manifestaba en

26 "H. C. Ørsted til H. C. Andersen, april 1834 [H. C. Ørsted a H. C. Andersen, abril de 1834]", en Breve fra og til H. C. Ørsted [Cartas de y dirigidas a H. C. Ørsted], vols. 1-2, Copenhague: Th. Linds Forlag, 1870, vol. 1, p. 28.

${ }^{27}$ Jens Baggesen (1764-1826), poeta y dramaturgo danés.

${ }^{28}$ H. C. Andersen, "Agnete og Havmanden”, en H.C. Andersens samlede varker 1-18, ed. por Klaus P. Mortensen, Copenhague: Det Danske Sprog- og Litteraturselskab, 2003-2077, vol. 10, p. 365. 
la vida de Andersen. En el verano de 1832 ansía salir de Copenhague y regresar a Odense, solo para constatar que ahora desea intensamente dejar su pueblo natal y volver a Selandia, de donde acaba de irse. Igual que un péndulo, oscila de un lado a otro sin encontrar un paradero firme. Desde Odense, el 11 de julio de 1832 le confía a Edvard Collin —con casi el mismo tono que en el prólogo de tiempo después- que ha concebido una idea para "un poema dramático parecido a Aladdin, es decir, Inés (basado en la famosa canción popular) (...) La fábula sugiere el profundo anhelo por ese 'no sé qué' y la insatisfacción con lo que se tiene". ${ }^{29}$

Este motivo real detrás del poema dramático aparece de forma principal en la historia previa que Andersen le da a su Inés y que es una adición totalmente suya. Inés ha nacido en los restos de un naufragio justo en el momento en que la madre es arrastrada por la marea; de este modo, se encuentra dividida desde el nacimiento entre dos mundos: la tierra y el mar. En un sentido externo, el tritón es un amante seductor y enérgico que contrasta con el torpe e insignificante Hemming. Sin embargo, para Andersen su significado es completamente distinto. Desde su punto de vista, él representa precisamente ese otro mundo hacia el cual una Inés ya adulta se arroja en su inquieto e indeciso anhelo por una existencia diferente. La esencia de Inés no posee un carácter demónico-erótico, sino que es el resultado de su origen doble. En cuanto figura poética, ella había sido diseñada deliberadamente, como se desprende de la carta a Collin, como una alternativa al armónico y espontáneo Aladdin de Oehlenschläger, cuyo origen humilde no planteaba ninguna dificultad y era, de hecho, su punto fuerte. La figura escindida de Inés constituía la imagen opuesta que Andersen proponía frente a aquella representación del artista, y un símbolo del tipo de artista reflexivo y profundamente perturbado, algo por completo diferente al modelo que la época profesaba firmemente como su ideal oficial. Un modelo en contra del cual no se podía escribir de forma impune.

Si H. C. Andersen depositó esperanzas tan grandes e irreales en su Inés y el tritón, fue principalmente porque con Inés creía haber conjurado y capturado en lo más profundo de su ser su propia esencia inquieta y propensa al nomadismo. Estaba convencido de haber creado una obra de arte que le proporcionaba una expresión objetiva a lo subjetivo. Pero se equivocaba.

29 "Andersen til Edvard Collin, 11. juli 1832 [Andersen a Edvard Collin, 11 de julio de 1832]", en H. C. Andersens Brevveksling med Edvard og Henriette Collin [Intercambio epistolar de H. C. Andersen con Edvard y Henriette Collin], vols. 1-6, Copenhague: Levin \& Munskgaards Forlag, 1933-1937, vol. 1, p. 29. 
No había puesto la distancia suficiente con respecto a sí mismo para ser capaz de transformar la esfera de lo privado. La áspera e irritada carta de Edvard Collin del 18 de diciembre de 1833 acerca del drama enviado a casa, aborda un punto central: "Es increíble cuán pocos amigos tiene su musa hoy en día. He aquí el motivo: ¡Escribe demasiado! (...) Inés es sin más un reflejo del viejo Andersen (...) Al hacer las pruebas, casi me pongo a llorar a causa del gran número de conocidos con los que me encontré en Inés y con los que no deseaba encontrarme; la mayor parte del tiempo, mi enfado sofocaba el llanto". ${ }^{30}$

A pesar de todo esto, Inés solo fracasó desde una perspectiva a corto plazo. Pues cuando, algunos pocos años después, Andersen contó la misma historia con algunas variantes — simples, pero decisivas- en el cuento de "La sirenita [Den lille Havfrue]" de 1837, consiguió llevar a cabo su idea: describir el fatal y trágico camino de un ser dividido en dos, y proporcionarle a este ser una forma mítica que fuera duradera. Por otra parte, también aprendió mucho acerca de sí mismo y de lo que podía hacer. Entre otras cosas de no poca importancia, con Inés y el tritón había adquirido conocimientos que podrían serle de ayuda más adelante. El carácter inquisitivo y excesivamente sensible de H. C. Andersen no solo era una carga para sí mismo y sus conocidos. Era también la causa de que, a diferencia de muchas otras personas, él no se encapsulara en sí mismo, llenándose de rencor, sino que aprendiera de sus errores y fracasos. Él, con su excesivo egocentrismo y susceptibilidad, fue capaz de extraer en sus mejores obras el elemento privado, y logró transformar sus profundas experiencias individuales en representaciones válidas y modelos que trascendieran lo personal. Un año y medio después de la crisis más importante de su vida, publicaría El improvisador [Improvisatoren] y —algo que pasaría de forma inadvertida en aquel entonces - la primera serie de cuentos de hadas, obras que, vistas desde la perspectiva de la posteridad, lo elevarían por encima de la mayoría de las producciones literarias danesas de la época.

\section{VII}

Después de la crisis del periodo entre 1833 y 1838, Andersen retomó su producción dramática y, en el largo intervalo de 1839 a 1855, sacó a la luz,

30 "Edvard Collin til Andersen, 18. december 1832 [Edvard Collin a Andersen, 18 de diciembre de 1832]", en H. C. Andersens Brevveksling med Edvard og Henriette Collin, vol. 1, p. 203. 
de forma progresiva, siete piezas breves y dieciséis obras más extensas. La comedia El hombre invisible de Sprogø [Den Usynlige paa Sprogø], estrenada en el Teatro Real el 4 de octubre de 1839, fue aclamada vivamente. La trama se desarrolla en Sprogø, donde unos compañeros de viaje quedan atrapados por el hielo en su camino de Copenhague a Løgstør. Al igual que en su primer vodevil, Amor en la torre de san Nicolás, la peripecia se da con un padre (el agente Blomme) que no quiere permitirle a su hija (Ingeborg) unirse con su favorito (Andreas Meier). Un tal Theodor Granner pone en marcha una elaborada intriga que involucra a todos en la isla y cuyo objetivo es hacerle creer al renuente e ingenuo agente Blomme que es capaz de andar de forma invisible. Sin embargo, cuando Blomme quiere volver a hacerse visible — pues en su calidad de fantasma permanecería atrapado por siempre en Sprogø_, Theodor establece como condición que le dé su aprobación a la joven pareja, lo cual hace. La pieza, que no pretende ser ni más ni menos que un juego alegre, explota la invisibilidad visible de Blomme, un tema que H. C. Andersen ya había abordado, aunque desde otro ángulo, en "El traje nuevo del emperador [Keiserens nye Klæder]". El truco de su primer vodevil vuelve a aparecer. Theodor concluye la obra dirigiéndose al público: “ ¡Una crítica severa destruiría / nuestra pequeña broma, nuestra bagatela!”. ${ }^{11}$ Por fortuna, el público tomó a bien las bromas y los números musicales.

Esto se convirtió en el primer paso de una apuesta de mayor alcance. El año siguiente, Andersen escribió cinco piezas dramáticas. El 3 de febrero de 1840, se estrenó en el Teatro Real con gran éxito El mulato [Mulatten]. Fue seguido, el 11 de marzo, por un vodevil en monólogo escrito para Phister, ${ }^{32}$ Las historias de amor de Mikkel en París [Mikkels Kjærlighedshistorier $i$ Paris], y redondeó la temporada de primavera con Una comedia al aire libre [En Comedie $i$ det Gronne], una adaptación bien lograda de la traducción de N. T. Bruun de 1809 (realizada a partir de la traducción de La fête de champagne, ou L'intendant comédien malgré lui). La comedia, en la que aparece un ataque en contra del estilo literario de Kierkegaard —retorcido y ampuloso, según Andersen-, se representó en la temporada de verano, el 13 de mayo, en el Teatro Real. En la temporada de otoño aparecieron dos obras más. El 7 de noviembre, un pequeño drama de situación titulado $\mathrm{La}$

${ }^{31}$ H. C. Andersen, "Den Usynlige paa Sprogø”, en H.C. Andersens samlede varker 1-18, ed. por Klaus P. Mortensen, Copenhague: Det Danske Sprog- og Litteraturselskab, 2003-2077, vol. 11, p. 273.

32 Ludvig Phister (1807-1896), actor danés. 
cantante [Sangerinden], y, el 18 de diciembre, La morisca [Maurerpigen], que, a diferencia de las demás, tuvo un recibimiento frío entre el público, aunque, de forma irónica, tuvo reseñas bastante buenas. La apuesta abarcaba desde el gran drama hasta el monólogo divertido, desde lo cómico hasta lo trágico.

El mulato. Drama original romántico en cinco actos, el título completo, se convirtió en uno de los éxitos teatrales más grandes de H. C. Andersen. El drama se basa en la novela "Les épaves" de la escritora francesa Fanny Reybaud, ${ }^{33}$ publicada bajo el seudónimo H. Arnaud en la Revue de Paris en febrero de 1838. H. C. Andersen, que de inmediato quedó prendado del tema, había trabajado de forma intensa en su dramatización en el periodo entre abril de 1838 y marzo de 1839. En lo fundamental, el drama sigue el argumento de la novela, la cual se desarrolla en Martinica, en las Antillas francesas, alrededor de 1720, aunque se omiten las fechas exactas que sí aparecen en la novela. A grandes rasgos, la historia cuenta cómo Eleonor, la joven esposa del brutal terrateniente y esclavista La Rebelliere, y su pupila Cecilia, son acogidas durante una tempestad por el amable e ilustrado mulato Horacio, quien ha recibido en herencia una gran propiedad después de haber sido educado por muchos años en Francia. Cuando La Rebelliere se entera de la pasión de su esposa por Horacio, quien no sospecha nada y que, mientras tanto, se ha enamorado de Cecilia y esta de él, lo apresa para a continuación ponerlo en venta en el mercado de esclavos. Se revela que Horacio ha nacido en su propiedad. Y cuando La Rebelliere se remite a la ley según la cual un hombre blanco posee derecho de vida y muerte sobre un hombre de color que lo ha ultrajado, Cecilia explica que desea casarse con Horacio y, de este modo, apela la acusación de su antiguo tutor señalando otro parágrafo de la ley que libera al hombre de color que es tomado en matrimonio por una mujer blanca.

La novela pone énfasis en el elemento psicológico: la crueldad brutal del cobarde La Rebelliere; la magnanimidad de Horacio, que aborrece el déspota; el odio de una hastiada Eleonor a su marido y su amor apasionado por el mulato; y la aversión ingenua de Cecilia por la esclavitud, su humanitarismo y su amor maduro. H. C. Andersen añade otro elemento que no se encuentra en la novela. Dicho elemento aparece en la dedicatoria a Christian VIII en la versión impresa:

${ }^{33}$ Henriette Étiennette Fanny Reybaud (1802-1870), mejor conocida como Madame Reybaud, novelista francesa. 
Con clemencia escuchaste nuestra canción,

En ella resuenan con vigor las luchas y triunfos del espíritu;

Homenajeas al espíritu como algo surgido de Dios,

¡Y es por ello, rey mío, que a ti te entrego esta canción! ${ }^{34}$

El rey representa una forma de manifestación del poder distinta a aquella que se sirve de la violencia física. Es en virtud de esta dimensión espiritual que el drama se eleva por encima de esa esfera pasional que a H. C. Ørsted le había parecido tan repelente en Inés y el tritón. De este modo, El mulato abordaba esa nobleza del espíritu de la que Andersen hablaba cada vez más en su producción literaria; el primer gran ejemplo de esto era su novela $O$. T. Frente a la nobleza que reside en propiedades y títulos heredados, Andersen apuesta por el ennoblecimiento que entraña una actitud humanitaria: la consideración por los demás antes que por los propios intereses, lo cual era un ideal de la burguesía (cristiana). La nobleza de corazón la encontramos - lo mismo que en el mundo de la realeza danesa, donde espíritu y nobleza eran la misma cosa - en la condesa Cecilia, que va más allá del orgullo propio de su condición y se sacrifica en virtud de su amor sublime — no un entusiasmo de carácter sexual- por Horacio, que con su naturaleza pura y magnánima manifiesta esa misma nobleza espiritual. Horacio lo formula de la siguiente manera: "Solo nosotros escribir podemos nuestro certificado de nobleza / Sellándolo con nuestro corazón y espíritu. / Detrás del vestido miserable palpita a menudo un corazón de rey, / El amo, en cambio, no alberga sino pensamientos de esclavo". ${ }^{35}$ Hacia el final de la pieza, Cecilia complementa estas palabras con el siguiente juicio sobre Horacio: “¡Sí, él se ha ennoblecido, ha sido ennoblecido por Dios!"36

Así, este drama traslada el enfoque del conflicto del elemento psicológico y el desafío abierto a la esclavitud que aparece en la novela, a uno de los temas fundamentales de la obra de Andersen: la figura del excluido, el despreciado, el repudiado. H. C. Andersen añade escenas de su propia confección para ilustrar parte del proceso de espiritualización que eleva al hombre segregado por encima de aquellos que tienen poder para desdeñarlo. En especial hay dos que son dignas de mención. En la primera se revela la naturaleza de Horacio, la cual es afín a la del artista:

${ }^{34}$ H. C. Andersen, “Mulatten”, en H.C. Andersens samlede varker 1-18, ed. por Klaus P. Mortensen, Copenhague: Det Danske Sprog- og Litteraturselskab, 2003-2077, vol. 11, p. 277.

35 Andersen, "Mulatten”, p. 330.

36 Andersen, "Mulatten”, p. 366. 
No, yo no veo tan solo a la hermosa oruga,

Yo busco el espíritu en cada fragancia y en cada color;

Para mí no constituye triunfo alguno

El mirar el movimiento de las manecillas,

No, el mecanismo en las partes del reloj

Yo deseo conocer a fin de comprender el conjunto. ${ }^{37}$

Lo mismo que el artista verdadero - y que el científico al estilo de Ørsted-, su fascinación por la naturaleza no permanece en la superficie sensible:

Un día de trabajo pasa diariamente frente a nuestros ojos,

Ante la mirada de miles flota una imagen de espuma,

Mas la poesía, la perla que ahí reside,

Solo el poeta cual intrépido buzo puede extraer. ${ }^{38}$

El diálogo entabla una polémica en contra tanto de la poesía cotidiana demasiado insulsa como de aquella que era demasiado etérea y alejada del mundo. Para Cecilia, por su parte, la compañía de este joven instruido e intelectual se convierte en una revelación de la profundidad del mundo. Se trata, pues, de una comprensión que solo puede procurar la poesía verdadera. De ahí nace el amor de Cecilia por Horacio. "Ha tocado él mis oídos y mis ojos, / y con cada día que pasa el mundo se torna un lugar prodigioso", ${ }^{39}$ explica en la importante segunda escena. Esta se desarrolla alrededor de la imagen de un gran árbol que extiende sus ramas hacia el cielo y siembra sus raíces en lo profundo de la tierra, una imagen que, por lo demás, resulta muy parecida a aquella que H. C. Andersen había empleado en $O$. T. para describir la esencia verdadera de la poesía. También semejante es lo que dice Cecilia sobre el influjo de Horacio:

Igual que un jeroglífico o que una pintura del alma

Es el imponente y bello árbol que él representa;

Algunas ramas se elevan a lo alto,

Estas beben de la luz y el viento, a fin de que las flores crezcan,

Otras de nuestra mirada se ocultan,

Pero es justo en ellas donde reside la savia más fuerte,

Las largas raíces se distribuyen de forma notable

$\mathrm{Y}$ escondidas se entrelazan en la totalidad del mundo. ${ }^{40}$

\footnotetext{
37 Andersen, “Mulatten”, p. 291.

38 Andersen, "Mulatten”, p. 295.

39 Andersen, "Mulatten”, p. 321.

${ }^{40}$ Ibid.
} 
En esta estrofa, H. C. Andersen ofrece una interpretación ennoblecedora de la realidad en la que se contiene un fin común para el arte de la época y la manera de hacer poesía. En la imagen del árbol, se invierte el sentido del crecimiento biológico. El árbol no toma su alimento de abajo, sino de arriba. Sus ramas absorben la luz y el viento y, de este modo, transmiten lo celeste a lo terreno, elementos que se enlazan en un todo en las raíces finamente distribuidas.

El hecho de que sea Cecilia la que propone esta "poética" es una consecuencia de su carácter. A diferencia de Eleonor, lo esencial del amor de Cecilia, como se ha dicho, no consiste en un entusiasmo físico, sino espiritual. La obra, claro está, no es solo bondad. A manera de introducción para esta dimensión espiritual de la pieza, Andersen se permitió al mismo tiempo - lo cual claramente era del gusto del público - representar el elemento demoniaco en el esclavista y en Paleme, el esclavo sin amo, todo esto sin arriesgarse a recibir represalias. Sobre todo, hizo posible que el público se sumergiera en pasiones impetuosas, aunque revestidas de tabúes. Tanto en el esclavista como en el esclavo sin amo se mezclan la feroz violencia física con la sexualidad desenfrenada. Estas características se acentúan cuando se las compara con el comportamiento de Horacio y Cecilia, pero también frente a la criolla apasionada, Eleonor, quien es por mucho la figura más interesante tanto en la novela como en el drama y que, al final de la pieza, se resigna y, así, se libera de su obsesión erótica por Horacio, limpia de todos sus prejuicios en contra de la gente de color. Inmediatamente después de su encuentro con Horacio, ella piensa que él es mitad animal, puesto que su madre era negra. A esto replica Cecilia, en consonancia con la idea fundamental del drama, que lo propiamente humano no reside en el color externo de la piel, sino en lo interior, en lo espiritual:

En el fango del cenagal alumbra la cálida luz solar

Y florece, blanco y puro, el lirio.

Los componentes mejores los absorbe con las hojas,

Obtiene su fragancia y color con el baño de luz. ${ }^{41}$

La metáfora del pantano se parece de forma notable a la descripción que $\mathrm{H}$. C. Andersen hace de sí mismo como una criatura de las profundidades en una carta a Henriette Wulff del 16 de febrero de 1833. En esta carta, Andersen esperaba lleno de inquietud e incertidumbre que el rey le concediera el dinero para su gran viaje: "Es menester que la planta del pantano crezca un

${ }^{41}$ Andersen, “Mulatten”, p. 309. 
poquito más, templada por los hielos y las tormentas; entonces el sol de la poesía ennoblecerá su savia”. ${ }^{42}$

La planta de pantano que es ennoblecida por el sol era una imagen de algo que, si bien de acuerdo con los estándares usuales resulta impuro e inferior, contiene dentro de sí un potencial que, cuando se manifiesta, rompe literalmente con el valor superficial de las normas.

\section{VIII}

Si bien El mulato tuvo una recepción entusiasta, su éxito no careció, sin embargo, de algunas discordancias. H. C. Andersen había olvidado señalar que la trama la había tomado prestada y se atrevió a afirmar que la pieza era original, sin duda porque estaba convencido de que esta obra era una creación suya en el mismo sentido que Aladdin era la obra de Oehlenschläger.

En el autocompasivo prólogo que aparece en la edición impresa de La morisca, Andersen se protege en contra de una crítica estrecha de miras, pero también comete el error táctico de contrariar a los reseñadores señalando que a través de toda su carrera se ha visto obligado a luchar en contra de un público reacio, situación que solo ha comenzado a cambiar con El mulato. De acuerdo con su propia interpretación, la rencorosa reseña anónima de Fædrelandet, al exagerar el asunto de la no referencia a Reybaud, lo había devuelto al punto de partida:

En esta situación decidí responder como lo he hecho, escribiendo una obra nueva con el mismo tema recién descubierto, y prestando atención a nuestro teatro y sus virtudes (...)

Ofrezco esta obra al público. Si se la lee no producirá el mismo efecto que El mulato; tiene menos episodios líricos. La pieza en su totalidad está diseñada para la escena, para su representación, y solo en este sentido debe ser juzgada. Hasta qué punto he corrido con fortuna es algo que el tiempo determinará. ${ }^{43}$

El tiempo, en efecto, decidió la cuestión. O mejor dicho: el público. El veredicto fue que Andersen no había corrido con fortuna. Semejante juicio

42 “Andersen til Wulff, 16. feb. 1833 [Andersen a Wulff, 16 de febrero de 1833]", en H. C. Andersen og Henriette Wulff, en Brevveksling [H. C. Andersen y Henriette Wulff, un intercambio espistolar], vols. 1-3, Odense: Flensted Forlag, 1959, vol. 1, p. 90.

${ }^{43}$ H. C. Andersen, "Maurerpigen”, en H.C. Andersens samlede værker 1-18, ed. por Klaus P. Mortensen, Copenhague: Det Danske Sprog- og Litteraturselskab, 2003-2077, vol. 11, p. 417. 
no era poco razonable. Como drama, La morisca adolece de una trama demasiado austera y sus personajes son superficiales. Por otro lado, el veredicto tampoco había sido completamente justo. La obra no es tan mala y, si se considera la producción literaria de Andersen desde una perspectiva histórica, la pieza no carece de importancia, pues en ella se vuelve a tocar el tema del desprotegido que tiene raíces en dos mundos diferentes. Mientras que Inés estaba dividida entre la tierra y el mar, y Horacio entre el espíritu libre francés y la esclavitud colonial, la protagonista de La morisca, la pobre huérfana Rafaela, ha sido educada como cristiana y se percibe a sí misma como cristiana. No obstante, como se revela más adelante, es hija del mismísimo rey de los moros. En el comienzo de la historia, ella se destaca por su valentía en la lucha contra los moros. El joven rey de Córdoba, a cuyo lado ella ha luchado, la llama y le pide su mano, a pesar de que su padre había decidido, en su lecho de muerte, que su hijo debía casarse con la hija del rey de Francia para así asegurar la existencia del reino. Desde la perspectiva del joven rey, ella es la hija del pueblo y, al casarse con ella, se casa con España misma. El rey se aferra a esta idea incluso cuando se descubre que Rafaela es la hija del rey de los moros, quien vuelve a intentar tomar Córdoba, aunque fracasa gracias a la firmeza de Rafaela. Cuando después de la batalla el rey repite su deseo de convertir a Rafaela en su reina, ella responde aparentemente que sí:

\footnotetext{
¡Prometo,

En este mismo instante,

Entregarme a mi nación!

¡Sí, entregarme! ${ }^{44}$
}

Estas palabras ocultan un significado distinto al que cree el rey, pues Rafaela no piensa en su enlace con él. En realidad, hace que la hija del rey de Francia se ponga su vestido y velo para que el rey, sin saberlo, se case con la mujer que podrá preservar su reino. En cuanto termina la boda, Rafaela se arroja a un profundo pozo para así salvar a su patria cristiana y al rey, a quien ama. De esta manera, Rafaela encarna la idea de Andersen de lo que es la nobleza de espíritu y de la identidad genuina que no se constituye a partir del nacimiento o del origen social o biológico, sino por medio del carácter humano propio de la persona. Ella sacrifica su vida por lo que ama y de forma consciente sale de la esfera del amor erótico y pasa al ámbito amor desinteresado. Sin embargo, esto último no debe interpretarse como

${ }^{44}$ Andersen, “Maurerpigen”, p. 500. 
el triunfo del amor cristiano sobre la crueldad morisca y pagana, pues el egoísmo del que se habla en La morisca no tiene que ver con el linaje o la cultura. El representante principal del egoísmo es el hidalgo Zavala. Rafaela ha aceptado su propuesta de matrimonio y se ha convertido en su esposa a fin de evadir la proposición del rey, ya que considera que ella, al provenir de lo más bajo de la sociedad, no es digna de un rey. Zavala, en cambio, representa al hombre orientado a la satisfacción inmediata, interesado solo en su deleite y beneficio: "Es preciso aprovechar la belleza del momento (...) Dichoso aquel / que echa mano a la riqueza que el instante le obsequia". Una vez que ha conquistado a Rafaela, pierde el interés por ella y, más adelante, traiciona a su rey y concierta una alianza con el rey de los moros, lo cual termina costándole la vida. Su antítesis no es solo Rafaela, sino también la media hermana de esta, Niama, la hija del rey de los moros, quien entiende el instante como un elemento más en "el tedio de la eternidad".

¡Aquello que es grande y hermoso no puede jamás morir!

Eso que cada espíritu cultivado produce aquí,

Permanece como un punto luminoso y brilla como una estrella

A través de los tiempos. Y nuevas estrellas nacen

Tan magníficas que muchas de las que hoy divisamos

Habrán de palidecer, pero todas se funden

Para gloria de nuestra tierra: la gloria de la ilustración. ${ }^{45}$

Este reconocimiento de lo ilimitado es causa también de que Niama se oponga amigablemente al odio apasionado de Rafaela en contra de los moros, señalándole que las diferencias religiosas son algo superficial:

$¿$ No crees acaso que una divinidad poderosa

Nos ha creado y nos ama

Más de lo que nosotros podemos amar?

¿No crees acaso que lo verdadero,

Lo bueno y lo bello

Se han convertido aquí en el mundo en el trítono

Que expresa la vida de la vida? ${ }^{46}$

Y a pesar de que Rafaela desdeña las palabras de Niama, "El mundo entero / Es nuestra gran patria" ${ }^{47}$ calificándolas como un discurso propio de un nómada, al final es Niama la que tiene la razón. Pues la patria por la que

\footnotetext{
45 Andersen, “Maurerpigen”, p. 454.

46 Andersen, "Maurerpigen”, p. 451.

${ }^{47}$ Andersen, “Maurerpigen”, p. 452.
} 
Rafaela se sacrifica al final no es su país natal, sino un conjunto inmaterial de ideas más elevado que no puede determinarse por consideraciones o intereses de carácter personal.

De esta manera, la obra expone un proceso de transformación que arranca a Rafaela de su odio a los moros _el cual ha sido inculcado en ella por su madre (quien ha sido violada) - y la conduce hacia esa perla oculta que la perspicaz Niama ha descubierto en la mirada de su media hermana: la capacidad para sacrificarse por algo que es más grande que uno mismo.

IX

Los años inmediatamente posteriores a los grandes éxitos de 1840 fueron menos febriles en el frente dramático. Una buena parte de ese tiempo fue ocupada por el viaje a Oriente entre octubre de 1840 y julio de 1841, y más tarde por la redacción de su descripción de viaje, El bazar de un poeta [En Digters Bazar], publicado en marzo de 1842. El 19 de diciembre de 1841, en cambio, se representó con gran éxito su popurrí operístico, Paseo a través de la galería de la ópera, una exposición declamatoria de una serie de escenas de obras antiguas y nuevas de compositores hechas para la escena danesa [Vandring gjennem Opera-Galleriet, declamatorisk Ramme for en SceneRække, af xldre og nyere Componisters Arbeider paa den danske Scene].

En julio de 1842, el vodevil El pájaro en el peral [Fuglen i Pzretzet] - con Johanne Luise Heiberg en el papel protagónico- tuvo una buena acogida. Como obra poética, en cambio, fue criticada por el marido de la actriz ${ }^{48}$ quien consideraba que las bromas eran superfluas.

La pieza está basada en la trama de la novela corta de Rosa Maria Assing, ${ }^{49}$ "Herr Thomas Brown und seine Nachbarn", pero traslada la acción de Londres a un contexto danés. El pedante y un poco testarudo canciller Arents está reñido con su jovial y sencillo vecino, el capitán Petersen. El meollo del conflicto es un peral en el jardín del capitán que alcanza a traspasar las tierras del canciller. Pero en el árbol vive el pájaro del amor, o dicho de otro modo, en el árbol, ahí donde se borran los límites entre las dos propiedades, se encuentran los dos jóvenes amantes: la hermosa hija del canciller y el audaz hijo del capitán. Al final de la historia, el capitán convence a su vecino de que acepte que los dos jóvenes se casen y se hagan cargo de la casa del capitán, y que la valla que hasta ese momento

${ }^{48}$ Es decir, Johan Ludvig Heiberg.

${ }^{49}$ Rosa Maria Assing (1783-1840), poeta alemana. 
había dividido las propiedades sea derribada, de manera que el peral pueda convertirse una vez más en un símbolo de amor y reconciliación más allá de rencillas mezquinas.

A decirverdad, la tramaligera y sin pretensiones no era del todo superflua. $\mathrm{Al}$ abordar de forma jocosa el tema de la presunción y la mezquindad, el vodevil armoniza completamente con la postura cosmopolita que se observa tanto en El mulato como en La morisca, así como en numerosos cuentos de hadas que H. C. Andersen escribió en los años cuarenta. Sin embargo, esto no supo apreciarlo Heiberg. Ni supo callar al respecto.

El año siguiente Inés y el tritón, pieza que H. C. Andersen había adaptado para la escena, tuvo un nuevo fracaso. De este modo, se volvió a abrir una vieja y profunda herida. No obstante, como muchas otras veces antes, el tenaz poeta se repuso de la derrota. En esta ocasión, lo logró con una de sus obras escénicas más originales, El sueño del rey [Kongen drømmer], pieza que alcanzó catorce representaciones en el periodo entre 1844 y 1857.

Aquí se pone en juego en tiempo real la dialéctica entre el pasado y el presente con la que había experimentado en Despedidas y encuentros. En cinco cambios de escena se alternan en tiempo y lugar los momentos decisivos en la vida de Cristian II. La obra comienza con el rey anciano que duerme en su encierro en el castillo de Sønderborg, y con su viejo y leal siervo, Benth, quien relata la vida del rey. Entonces la niebla cubre la escena y cuando vuelve a clarear nos encontramos en Bergen, donde el joven príncipe se enamora de la hermosa, intrépida y agresiva Dyveke. Una vez más la escena se oscurece y volvemos a la prisión, donde Cristian confiesa estar soñando un sueño de juventud. Otra vez se duerme y Benth continúa relatando la historia hasta el envenenamiento de Dyveke en Copenhague. La escena cambia nuevamente y presenciamos el sueño-recuerdo del asesinato orquestado por el noble Peder Oxe, después de lo cual regresamos a la prisión en Sønderborg, donde Benth habla sobre la transformación del carácter de Cristian después de la pérdida de su amada:

Fue entonces que tu buen ánimo desapareció;

¡La habían asesinado, a Dyveke!

Y feroz y sombrío se tornó tu semblante (...)

Apresaste con vigor al noble,

Lo mismo que el noble apresa al pobre; quebraste las alas

Del cuervo altivo; (...)

¡Tu corazón abriste al humilde! ¡Eras sabio y valiente!

Tu corazón y tu cabeza guiaban la pluma 
Cuando redactabas leyes, pero fue tu ángel maligno

Quien movía el brazo cuando alzaste la espada. ${ }^{50}$

De esta forma se enlazan en la obra dos temas principales: la historia de amor y la historia política. Para Andersen, Cristian II es el rey del pueblo que se enfrenta al explotador y enemigo de la gente: la nobleza. No obstante, aunque es claro que en la pieza se toma partido por el rey en contra de la nobleza, también se censura su comportamiento sanguinario, algo que, en la interpretación de Andersen, puede observarse en la mezcla confusa entre la pena y la herida personal del rey por el envenenamiento de la amada, y su original postura favorable frente al pueblo, en la cual se supone que el rey se encuentra por encima de cualquier interés particular, a diferencia de la nobleza, que se deja conducir por el egoísmo.

Al final de la obra, en el encuentro con Cristian III, el rey vuelve en sí. Frente al lecho de muerte de Benth, se reencuentra con su antiguo yo y, dirigiéndose al nuevo rey, exclama: “¡Rey! ¡Mira! / ¡Un hombre del pueblo! ¡Sé bueno con el pueblo! / ¡Es la fuerza y el corazón del país!”

A partir de este punto, la obra profundiza, al igual que el rey de Córdoba, en el reconocimiento del pueblo como fundamento del poder real.

\section{$X$}

En Inés y el tritón, H. C. Andersen había descrito el desgarrador anhelo de un ser humano por un sitio o una existencia diferente a la que le ha sido otorgada. Este tema lo retoma en su cuento de hadas "Los zapatos de la suerte" de 1838, en el que dicho anhelo se manifiesta a través de distintos personajes humorísticamente ilustrados. Ambas obras expresan una dura verdad: el mejor de todos los mundos es aquel en el que uno se encuentra. En La flor de la felicidad [Lykkens Blomst] —representada en febrero de 1845 y recibida favorablemente por el público, aunque no tanto por los reseñadores-, H. C Andersen aborda una vez más el tema de que la felicidad se encuentra en un lugar distinto a ese en el que uno está. Sin duda, esta insistencia se debía a que él mismo era incapaz de atenerse a su propia moraleja de evitar esa clase de añoranzas. Sin embargo, mientras que en las primeras obras el anhelo se origina en el interior de los personajes,

${ }^{50}$ H. C. Andersen, “Kongen drømmer”, en H.C. Andersens samlede værker 1-18, ed. por Klaus P. Mortensen, Copenhague: Det Danske Sprog- og Litteraturselskab, 2003-2077, vol. 12 , p. 35 .

${ }^{51}$ Andersen, “Kongen drømmer”, p. 42. 
aquí proviene del exterior, lo que le proporciona al conflicto un carácter notoriamente artificial. En esta obra hay más magia que psicología.

El guardabosque Henrik vive consciente de su gran dicha y no desea más vida que la que ya tiene con su Johanne y su pequeño hijo de un año en Jægersborg Dyrehave. Pero un gnomo bromista está convencido de que existe una felicidad superior para Henrik y, con la ayuda de dos perlas mágicas - y a pesar de las objeciones de Kirsten Piil—, lo transforma en dos figuras históricas, primero en el poeta Johannes Ewald ${ }^{52}$ y luego en el príncipe Buris ${ }^{33}$ :

Lo mismo que un actor ya no es él mismo,

Sino solo aquel que representa,

Así también él, por medio de un poderoso bautismo,

Cambiará lugares con ese al que estima el más dichoso. ${ }^{54}$

La lección que Henrik aprende gracias a esta pérdida de sí mismo no es nueva: la felicidad reside en la vida que ya tiene, algo que él ya sabía. Lo anterior armoniza perfectamente con la brevísima noción central de la pieza, la cual es expresada desde un principio por Kirsten Piil en oposición al entrometido gnomo: "Cualquier dicha consiste en creer en ella". ${ }^{55}$ Enseguida explica con más detalle este sencillo mensaje, el cual es repetido por Henrik al final de la obra:

La felicidad no reside en la riqueza,

(...)

No reside tampoco en el rango, en un nacimiento ilustre,

O en la fama inmortal adquirida a través de mil luchas.

La verde hoja de laurel no hace sino ocultar un veneno.

${ }^{52}$ Johannes Ewald (1743-1781), poeta danés, conocido por llevar una vida tormentosa aquejada por la depresión y el alcoholismo.

${ }^{53}$ La reina Sofía, esposa del rey Valdemar I (1131-1182) de Dinamarca, le propuso a su marido lo siguiente: la hermana del monarca, la llamada "pequeña Kirsten”, se casaría con el hermano de la reina, el príncipe Buris. El rey, sin embargo, rechaza la propuesta, señalando el bajo origen de Buris. La reina, ofendida, trama su venganza y, estando Valdemar ausente, convence a Buris de que seduzca a Kirsten. Los jóvenes se enamoran y Kirsten queda encinta. Cuando el rey se percata de lo que ha ocurrido, se enfurece y mata a Kirsten; a Buris, en cambio, lo mutila, para encerrarlo después en un calabozo cercano a la tumba de la pequeña Kirsten.

${ }^{54}$ H. C. Andersen, "Lykkens Blomst”, en H.C. Andersens samlede værker 1-18, ed. por Klaus P. Mortensen, Copenhague: Det Danske Sprog- og Litteraturselskab, 2003-2077, vol. 12 , p. 63.

55 Andersen, "Lykkens Blomst", p. 61. 
No, la dicha consiste en comprenderse mutuamente,

En gozar con las pequeñas cosas, en amarse con lealtad,

$Y$ en verte a ti mismo renacer en tu hijito. ${ }^{56}$

De este modo, la enseñanza de la obra no se deduce, sino que se confirma de modo radical a partir de las dos visitas interiores que Henrik hace a las figuras históricas. Debido a esto, su propia historia parece convertirse en un mero pretexto para lo fundamental: la profundización de dos situaciones interesantes. Lo que el espectador aprende en la obra es el carácter de estas situaciones, no la esencia de la felicidad.

La imagen de Ewald como el poeta jovial y brillante queda destruida con la descripción pormenorizada de un artista que yace en Rungsted enfermo, solo, incapacitado y humillado por un mundo que no lo comprende. Ahí compone con entusiasmo su oda "Las delicias de Rungsted", inspirado por la joven y compasiva Arenze (Andersen escribe así su nombre). El don poético se enciende una vez más en Ewald, quien al mismo tiempo es completamente consciente de que se trata de una última y breve llamarada, pues su vida ya la ha desperdiciado. La historia de amor no se repite con la nueva Arendse. En cambio, las posibilidades jamás realizadas en la primera historia de Arendse comienzan a manifestarse en el ambiente alrededor suyo. Un campesino pobre se acerca con su esposa y su pequeño hijo, un reflejo de la realidad soñada de Henrik. Con esta visión, en la que un ilusorio prestigio de artista cede el paso a una dicha genuina y sencilla, aunque inasequible para él, Ewald se hunde en la desesperación y Henrik se separa de él. Henrik despierta, pero de inmediato queda expuesto a la segunda perla mágica.

Provocado por el gnomo, Henrik pide que lo sitúen en una época más caballeresca que la de Ewald, y es enviado al momento histórico en el que el cruel y despótico rey Valdemar decide ponerle un alto al amor entre el príncipe Buris y la pequeña Kirsten. Mientras que el episodio de Ewald se centra en los pensamientos enfermizos del poeta, aquí el énfasis no recae en los protagonistas, pues a pesar de que la idea es que Henrik experimente la tragedia amorosa del príncipe Buris, este solo aparece en el comienzo y al final. La mayor parte del drama se observa desde fuera. De esta manera, H. C. Andersen dibuja una imagen pintoresca del momento histórico vista desde la perspectiva crítica (frente al poder real) del hombre sencillo, pero abandona el punto principal, la idea de una compenetración, con lo cual se

${ }^{56}$ Andersen, "Lykkens Blomst”, p. 64. 
pierde el último remanente de credibilidad escénica y psicológica.

Mucho mejor lograda fue la comedia La nueva babitación de la parturienta [Den nye Barselstue], estrenada en el Teatro Real un mes después. El público estaba entusiasmado y, por una vez, la crítica fue favorable. Se trata de una crítica aguda en contra del arte superficial, del esnobismo de los artistas y de su inclinación a la adulación recíproca. Andersen presenta, por ejemplo, la descripción entusiasta que un compositor hace de su nueva obra El diluvio:

¡Se trata de una gran pintura hecha con notas musicales! ¡Su importancia es inmensa! Empieza con música para bailar y con lo que yo llamo un "alarido obsceno", el cual insinúa la corrupción de los tiempos. Entonces viene la lluvia. Los ríos se desbordan, el mar se agita. Enseguida escuchamos la plegaria de la familia de Noé y los animales entran al arca. Todo ocurre de acuerdo con la naturaleza: el león ruge y el cordero bala. ${ }^{57}$

Los críticos admitieron que la pieza era graciosa, aunque también pensaron lo mismo de la reseña aparecida en Flyveposten, en la cual se hacía mofa de la estrechez de miras del poeta en su trato de la crítica literaria y artística. $\mathrm{H}$. C. Andersen reniega de "el elemento productivo, ennoblecedor y benéfico que, en términos generales, es parte del quehacer de los 'diarios' y que en buena medida tiene en consideración incluso lo producido en estas humildes páginas". 58

Con independencia de lo que pueda pensarse de la postura del reseñador, lo cierto es que había dado en el clavo con Andersen, pues debajo de su apariencia inofensiva, La nueva habitación ofrecía una imagen mordaz, incluso destructiva, de la pomposa vida cultural en Copenhague y de sus leyes de carácter mafioso. Todo esto desde la perspectiva llena de prejuicios del sufrido poeta Andersen. La obra, que presenta una serie retratos caricaturescos, se enfoca en la figura del poeta Jespersen. Este ha dado a luz por vez primera una pieza de cierta notoriedad artística, el drama Amor, y ahora la gente lo visita para felicitarlo por el parto dichoso. Pero en realidad él no es el progenitor de la obra maestra. El autor es su viejo amigo y hombre de mundo, el doctor Wendel, quien recién ha vuelto a casa después de pasar quince años en Sudamérica. El doctor, a quien todo mundo creía muerto, había dejado su país decepcionado tras su rechazo por parte de la

${ }^{57}$ H. C. Andersen, “Den nye Barselstue”, en H.C. Andersens samlede værker 1-18, ed. por Klaus P. Mortensen, Copenhague: Det Danske Sprog- og Litteraturselskab, 2003-2077, vol. 12, p. 153.

${ }^{58}$ Kjøbenhavns flyvende Post, no. 72, 28 de marzo de 1845. 
hermana de Jespersen, la sobria y aguda Christine, y su obra habla sobre su amor por ella. Solo ellos dos se sustraen a la sátira. Ahora quiere intentar conquistarla una vez más y promete no revelar las circunstancias detrás. De esta manera, la pieza concluye con un feliz auto-engaño y una picante ironía. No hay que creer en las ilusiones de la gente cultivada:

\section{FRU JESPERSEN}

¡Dios mío, qué cosas debes sentir! ¡Qué felicidad la de ser un poeta como tú!

\section{JESPERSEN}

¡Vaya que sí! ${ }^{59}$

\section{$X I$}

Después de una serie de éxitos relativos en la primera mitad de los años cuarenta, H. C. Andersen tropezó con dificultades. En primer lugar, la ópera La náyade [Nøkken], la cual había entregado al Teatro Real en marzo de 1845 , no fue representada a tiempo, y cuando esto finalmente ocurrió, la recepción no fue buena. La floja historia de amor de la pieza se desarrolla en Suecia y plantea una situación insólita. El personaje enigmático que, según se insinúa, es la náyade, en realidad no es un hada, sino la joven reina Cristina, quien intenta unir a dos jóvenes amantes. En segundo lugar, Andersen se enfrentó al segundo gran fracaso de su carrera con la comedia El señor Rasmussen [Hr. Rasmussen], estrenada el 19 de marzo de 1846 y representada en una sola ocasión. La trama es divertida y, por su forma satírica, se asemeja a La nueva habitación de la parturienta con sus personajes cómicos, todos ellos con un punto en común: un ridículo amor propio. La obra hace gala de lo mejor de H. C. Andersen como dramaturgo: pequeñas escenas de un humor mordaz en las que los personajes revelan sus caracteres a través de sus parlamentos, una característica también presente en sus novelas y en algunos de sus cuentos de hadas. El señor Rasmussen es un collage humorístico, en ocasiones casi anárquico, de observaciones ingeniosas y satíricas. Es también un ataque en contra de los críticos y de las polémicas políticas de la época. Pero como en muchas otras ocasiones, Andersen no pudo mantener el paso. En la última parte de la obra, se enfrasca en una compleja búsqueda del verdadero origen del personaje que le da su nombre a la pieza.

59 Andersen, "Den nye Barselstue”, p. 157. 
La obra se desarrolla en una hacienda en Fionia. En realidad no hay un protagonista. El drama obtiene su nombre del bonachón y desafortunado ex bailarín, el señor Rasmussen, quien está platónicamente enamorado de un seminarista. Rasmussen lee con entusiasmo la afectada carta del seminarista frente a su viejo conocido de Copenhague, el pintor Kryger, quien recientemente ha recibido un pago de 200 táleros por su pintura de una muchacha que se asoma por la ventana de un carpintero, a través de los ataúdes infantiles en exhibición, mientras juguetea con unas rosas. En la carta, Rasmussen recibe por fin el reconocimiento que nunca había tenido como bailarín, mientras que, por su parte, el seminarista obtiene la ocasión de lucirse con su recién adquirida erudición y habilidad lingüística. El estilo del discurso no le envidia nada a Holberg:

\begin{abstract}
RASMUSSEN (lee)
" iSi las bellas artes fueran mi oficio en lugar de lo preciso y provechoso, entonces le aseguraría a usted con un lenguaje más esmerado - aunque no más genuino- y con palabras mejor elegidas —aunque jamás mejor intencionadas- que usted es, en cuanto hombre y bello espíritu, lo más notable y afortunado con lo que me he cruzado en mis andanzas! Le juro y confieso que las horas que he pasado hablando y discutiendo con usted hacen parte ya de los momentos más imborrables de mi vida”, etcétera. ¿Has escuchado algo semejante?
\end{abstract}

KRYGER

¡Ya me imagino qué clase de seminarista es ese! ¡Felicitaciones!

Este mismo Kryger es, junto con la señorita Grethe, el único personaje pasablemente razonable de la obra (aunque ninguno de los dos lo es por completo). Al final terminan juntos. Alrededor de esta historia de amor -la cual culmina con la institución familiar y representa, de este modo, el ideal de la norma-, Andersen expone muchas otras formas de amor. Está la condesa, cuyo amor maternal es tan ciego e ilimitado que su grosero hijo de doce años, Napoleón, logra salirse con la suya incluso con las más graves travesuras (el título original de la obra era Napoleón segundo).

También está, por ejemplo, la solterona y alcahueta Jakobine, que le pone ropa a la estatua de Venus porque el obispo viene a almorzar. O la otra solterona, Caroline de Copenhague, quien, por un lado, siente pasión por la juventud políticamente progresista, con Orla Lehmann ${ }^{60}$ a la cabeza,

${ }^{60}$ Orla Lehmann (1810-1870), político liberal danés. Fue uno de los actores principales en la transformación de Dinamarca en una monarquía constitucional. 
aunque, por otro lado, le gustaría, de la forma más burguesa posible, poderse invitar a sí misma a la casa nueva del vecino, y está convencida de que la belleza se conserva mejor cuando uno no se casa. Por no mencionar a la tercera solterona de la pieza, la entusiasta del arte Laide, quien es "una conocedora de Thorvaldsen ${ }^{61}$ y de todo cuanto es italiano" ${ }^{22}$ : "He analizado con precisión las Gracias de Thorvaldsen. Yo conozco los estándares de la belleza". ${ }^{63}$ Más adelante, la conocedora Laide adula al engreído chambelán:

\section{CHAMBELÁN}

“¡Me ocupo de todo un poco y las más de las veces lo hago por juego!” Eso dice Calderón o Lope de Vega. ¡Es algo español!

\section{LAIDE}

¡Usted es un artista, un poeta! ¡Se nota a leguas! ¡Usted sabe cómo adornar a la naturaleza! ¡Cómo da gusto, es como si se anduviera sobre un lienzo espiritual! $!^{64}$

A través de la fuerza satírica, se puede atisbar la irritación por la ligereza insoportable de la cultura. En efecto, detrás de estas pequeñas descripciones satíricas de las singulares formas en que se manifiesta el amor, se oculta una historia acerca de la discreta doble moral burguesa, lo cual sale a la superficie en el segundo y último acto de la obra. Jakobine resulta ser la tía huérfana de Rasmussen, y Kryger, su medio hermano.

Como sucede con frecuencia en sus comedias y en varios de sus cuentos, relatos y novelas, Andersen maniobra con la doble moral burguesa y la introduce discretamente por la puerta trasera de la obra, exponiendo, de esta manera, a esa misma burguesía que se había mostrado tan ofendida con la figura de Inés. El humor de Andersen casi siempre es ambiguo. Como en muchas partes de su obra, el humor constituía una forma de protegerse y de endulzar los tragos amargos. Como se sabe, solo el ladrón piensa que todo mundo roba.

${ }^{61}$ Bertel Thorvaldsen (1770-1844), importante escultor danés. La escultura de las tres Gracias con Cupido (1821) es una de sus obras más importantes.

${ }^{62}$ H. C. Andersen, “Hr. Rasmussen”, en H.C. Andersens samlede værker 1-18, ed. por Klaus P. Mortensen, Copenhague: Det Danske Sprog- og Litteraturselskab, 2003-2077, vol. 12, p. 178.

63 Andersen, "Hr. Rasmussen”, p. 199.

${ }^{64}$ Andersen, “Hr. Rasmussen”, p. 176. 
La obra literaria de H. C. Andersen oscilaba constantemente, al igual que su estado de ánimo, entre la luz y la oscuridad. Desde 1839, Andersen había trabajado —entre largas interrupciones- en el proyecto de un gran drama para ser leído basado en la figura de Ahasverus. Ahora que estaba encasillado como autor cómico, había conseguido terminar este drama serio. Lo entregó para su publicación en 1847. La pieza aparece como una especie de interludio en su obra dramática antes de su última gran fase productiva entre el final de los años cuarenta y los siguientes diez años. Con su amplia perspectiva histórica, Ahasverus. Un poema dramático [Ahasverus. Et dramatisk Digt] representa un cambio de género. No puede decirse que este drama sea una comedia o una tragedia, y, en este sentido, se trata de un caso aislado. Por otra parte, el tema de la pieza ocupa un puesto central en la obra literaria de Andersen. El 13 de agosto de 1839, Andersen le escribe con tono patético a Henriette Wulff: "Incluso voy a la deriva como el desdichado Ahasverus. ¡No conozco el sosiego ni la dicha! Me comprendo a mí mismo y a mi porvenir mejor que cualquier otro mortal" . ${ }^{65}$ Ahasverus es un intento más por darle a su sentimiento de desarraigo una forma visible. En esta ocasión, por medio de una de las figuras místicas tardías de Occidente, el zapatero de Jerusalén, el judío errante, condenado a vagar sin reposo hasta el final de los tiempos, es decir, hasta el regreso de Cristo, pues se negó a darle asilo en su paso con la cruz hacia el Gólgota.

Así, no se debe interpretar a Ahasverus como una persona en el sentido corriente, sino como una figura en la que la sangrienta historia de la civilización europea y cristiana se cristaliza a grandes rasgos. El 14 de julio de 1843, cuando los planes para la obra estaban preparados, H. C. Andersen le escribe a Henriette Wulff: "En esta ocasión, mi musa no se pasea por el bosque de la fantasía, (...) sino que vuela con alas vigorosas por encima de la totalidad de la vida del mundo. La humanidad entera queda debajo de nosotros; me parece como si Dios se extendiera sobre este vuelo". ${ }^{66}$ De este modo, Ahasverus es al mismo tiempo un drama histórico e ideológico. Se trata de un intento en gran escala por presentar de forma

65 “Andersen til Wulff, 10. feb. 1841 [Andersen a Wulff, 10 de febrero de 1841]", en Breve fra Hans Christian Andersen, ed. por C. A. Bille y Nikolaj Bøgh, vol. 2, Copenhague: Reitzel, 1878, p. 19.

66 "Andersen til Wulff, 14. juli 1843 [Andersen a Wulff, 14 de julio de 1843]", en $H$. C. Andersen og Henriette Wulff, en Brevveksling, vol. 1, p. 336. 
condensada el sentido y la fuerza motriz de la historia. Al final del drama se dice a modo de resumen: "Aquello que resuena en lo profundo del mito de Ahasverus / Es un eco de las poderosas olas del tiempo". ${ }^{67}$

Esta fuerza motriz, sin embargo, no aparece sin más como una voluntad divina y abstracta. Para H. C. Andersen, el motor principal de la historia de la humanidad es la duda. El drama abre con un "primer plano" en el que se relata la historia en la que el ángel de la soberbia, Lucifer, se alza en contra de Dios y cae derrotado. Pero no estaba solo. El más débil de los ángeles rebeldes es Ahas, que rechaza y repudia todo aquello que no puede comprender. Ahas cae al mundo, donde aparece como un niño recién nacido con su madre. No tiene recuerdo alguno de su pasado.

El ángel de la esperanza profetiza que Ahas recobrará sus recuerdos perdidos; se arrepentirá y ascenderá una vez más al cielo del que ha caído, pero esto habrá de ocurrir en un futuro todavía indeterminado. A través de una larga serie de acontecimientos concretos, desde la entrada de Jesús en Jerusalén y la crucifixión hasta el descubrimiento de América por parte de Colón, H. C. Andersen describe la historia del cristianismo con Ahasverus como observador y partícipe violento en las transformaciones y episodios decisivos. La perspectiva superior no es la de Ahas, quien recibe el nombre de Ahasverus, pues él es el objeto de unas fuerzas que no comprende y a las que, en consecuencia, se opone. Estas fuerzas se manifiestan al lector a intervalos regulares a través de mensajeros, casi siempre ángeles, aunque también mediante el mismísimo Espíritu del mundo. De acuerdo con la limitada comprensión de Ahasverus, el Nuevo Testamento es una adulteración de la fe; él afirma la idea de que el Mesías judío es un rey terrenal, un nuevo David, pero los acontecimientos lo refutan una y otra vez. No obstante, poco a poco empieza a dudar de su propia duda. El cristianismo no solo resiste todos los embates en su contra, sino que se fortalece terrenal y espiritualmente. Después de la penitencia de Enrique IV en Canossa ${ }^{68}$ Ahasverus exclama:

${ }^{67}$ H. C. Andersen, “Ahasverus. Et dramtisk Digt”, en H.C. Andersens samlede værker 1-18, ed. por Klaus P. Mortensen, Copenhague: Det Danske Sprog- og Litteraturselskab, 2003-2077, vol. 12, p. 349.

${ }^{68}$ En 1077, el emperador Enrique IV (1050-1106) se enfrentó al papa Gregorio VII en la que fue conocida como la querella de las investiduras. Como represalia, Gregorio VII excomulgó al emperador, quien se vio obligado a humillarse peregrinando en ropaje de monje a Canossa, donde le rogó al papa que lo liberara de la excomunión. 
De singular manera se agita en mi pensamiento

La idea de yo soy la suma total

De la lucha del mundo en contra de lo divino,

Como si fuera yo una poderosa luz del intelecto

Que no se extingue bajo tormenta alguna.

¡Siento vértigo! ¿Qué es el pensamiento? ${ }^{69}$

Los ángeles responden su pregunta sin que Ahasverus pueda escucharlos: "Lo que de Dios viene a Dios irá, pero ni siquiera los ángeles saben cuándo" .70

Esto era también válido para H. C. Andersen. Él estaba atado al mito y, en consecuencia, era incapaz de acompañar a Ahasverus a su salvación en el momento de escribir el drama. Por otra parte, esa no era su tarea. Su objetivo, en cambio, era investigar la duda y alcanzar una mejor comprensión de la fuerza motriz fundamental de la historia. Es en este orden de ideas que recurre, hacia el final del drama, a las figuras de Gutenberg y Colón para destacar lo que, desde su punto de vista, era el punto de inflexión en esta historia de la duda. A saber, ese momento en el que por primera vez queda claro que la duda surge de la obstinación en contra de lo divino, aunque, precisamente en virtud de eso, está en armonía con los planes divinos. Es un monje dominico quien formula la tesis principal del drama en torno al oculto propósito divino de la duda. Esto se lee en su conversación íntima con Ahasverus:

Desde tiempos inmemoriales se posa en la jaula del universo

Un águila cautiva con relámpagos en las garras.

Muchos han intentado romper sus cadenas,

Pese a que ellos mismos no sabían por qué o con qué fin.

Su instinto los movía. La cadena limaron

Hasta que no fue más que una hebra; y aquel que limó por último

Fue ese Gutenberg. Ahora el águila levanta el vuelo

Y con su relámpago escribe cada uno de los pensamientos de los mortales.

AHASVERUS

¿Y qué? ¿Qué resultará de eso?

DOMINICO

Un escalofrío, me parece. Todos los reyes de reyes

Han sentido un escalofrío.

AHASVERUS

¿Y cómo se llama?

${ }^{69}$ Andersen, “Ahasverus”, p. 323.

${ }^{70}$ Ibíd.

Estudios Kierkegaardianos. Revista de filosofía 2 (2016) 


\section{DOMINICO}

¡Satán! ${ }^{71}$

Lo que los lectores saben y Ahasverus no, es que si el dominico sabe tanto es porque se trata del mismísimo Lucifer. Desde su perspectiva de caído, en esta generación habita "una llama del espíritu" que "conoce los secretos del cielo". ${ }^{72}$ Aquello que originalmente —antes de la rebelión y la caídaera una convivencia inconsciente con lo divino, se transformará, gracias al desarrollo irreflexivo y espontáneo de la oposición frente a un pensamiento complaciente, en un retorno a lo divino dirigido por la razón humana.

Desde esta perspectiva demoniaca, Colón debe interpretarse como alguien que intenta tomar el cielo por asalto y no como un insensato, que es como Ahasverus lo considera en un comienzo. Ahasverus, quien acompaña a Colón en su viaje decisivo, piensa en principio que el navegante terminará como una medusa eternamente a la deriva por los océanos del mundo. Pero Ahasverus se equivoca una vez más, pues cuando Colón vislumbra tierra, los marineros piden perdón por haber dudado de él y, de forma espontánea, formulan una tesis determinante cuyas implicaciones, sin embargo, apenas pueden comprender: “¡Perdón, perdón! ¡Un Dios habita en usted!” 73

La historia fundamental cristiana se interpreta aquí audazmente como un relato de cómo el hombre se hace consciente de lo divino dentro de sí. Una consciencia que se manifiesta en una comprensión cada vez mayor del funcionamiento del mundo. Gutenberg y Colón son grandes hombres prácticos que entienden cómo funciona el mundo y, en ese sentido, son capaces de descubrir el espíritu en el mundo. Hacia el final del drama, aparece el "Espíritu del mundo", quien toma la palabra de inmediato. Desde el punto de vista del Espíritu, el descubrimiento de un nuevo mundo representa un paso decisivo para que el hombre se percate de la presencia de la voluntad divina en todos los asuntos humanos. Esto ocurre en el ajuste de cuentas con Israel, donde también aparece la idea del Mesías que ha acompañado a Ahasverus desde el comienzo:

¡Oh, Israel! ¡Tú estuviste en la misma situación de América!

(...)

Eres la imagen de lo establecido.

¡Justo ahí estriba tu ruina, oh, pueblo de Israel!

Vagabundo eterno, fuiste testigo de lo ocurrido,

${ }^{71}$ Andersen, “Ahasverus”, p. 336.

72 Andersen, "Ahasverus”, p. 337.

${ }^{73}$ Andersen, "Ahasverus", p. 343. 
El género humano fue tu espejo.

Lo antiguo rechaza siempre a lo nuevo,

¡Dios nace, es crucificado... y vive!

Existe una regla común para todas las etapas de la historia que puede resumirse con la siguiente fórmula: nacimiento, muerte y resurrección. Las formas antiguas y anticuadas intentan luchar en contra de las innovaciones, pero es precisamente por esto que las nuevas formas ganan terreno. Por un breve segundo todo se vuelve claro para Ahasverus, pero de inmediato vuelve a la oscuridad. La fusión de espíritu y naturaleza que es Cristo no es todavía una realidad.

De esta manera, Abasverus se distingue notablemente de una serie de dramas de Andersen en los que lo más importante era satisfacer las expectativas del público en lo referente a las prácticas comunes del género, proporcionándole a la tragedia o comedia en cuestión una conclusión razonable. En Abasverus, Andersen insiste - al igual que en otras de sus mejores obras - en aquello que permanece inconcluso, en el desarraigo, en el carácter de provisional como una condición fundamental y necesaria de lo humano. Una condición también de lo artístico. Al final, el coro de ángeles establece la poética orden del día: "Haced sonar vuestras arpas, bardos de la tierra, / Que la historia universal y cada quien por su parte / Sean testigos del nacimiento del espíritu, de su lucha y su gloria”. ${ }^{74}$

Lo que es digno de mención y resulta provocativo es que aquello sobre lo que Abasverus arroja luz no es la fe, sino la duda. Solo esta puede impulsar el crecimiento del espíritu. Es algo que da en qué pensar.

\section{XIII}

Si bien la recepción de Ahasverus fue positiva, casi reverente (la palabra "genial" apareció en más de una reseña), no fue suficiente para sosegar las penas teatrales de H. C. Andersen. Especialmente en la segunda mitad de los años cuarenta, había comenzado a hartarse del Teatro Real, en específico a causa del influyente Heiberg, quien se convirtió en miembro de la dirección del teatro en 1839 y que, de acuerdo con Andersen, se dedicaba a acosarlo. Cuando en diciembre de 1843 Andersen entregó El sueño del rey, lo hizo, en consecuencia, de forma anónima. Y cuando, con ocasión de la admisión de La flor de la felicidad, tuvo un disgusto mayor con el poderoso crítico

\footnotetext{
${ }^{74}$ Andersen, "Ahasverus", p. 349.
} 
y censor, quien opinaba que la pieza era una abominación y que, por lo demás, el buen Andersen hubiera hecho bien en imitar su propio Día de los siete durmientes [Syvsoverdag] de 1840, este decidió entregar La nueva babitación de la parturienta también de forma anónima, aunque Heiberg había podido adivinar con facilidad quién era el autor de El sueño del rey.

Así, aunque esto parecía una simple táctica de avestruz, Andersen —a diferencia de la primera vez- mantuvo oculta su autoría, incluso después de la buena recepción. No fue sino hasta 1854, cuando el drama apareció en sus Escritos reunidos [Samlede Skrifter], que Andersen reconoció su paternidad. Y mantuvo la estrategia del anonimato con El señor Rasmussen, lo cual, como se sabe, no impidió que tuviera una recepción terrible. Su relación con el teatro tampoco cambió demasiado cuando se atrevió una vez más a asomar la cabeza con la pequeña pieza de ocasión El Dannevirke del arte [Kunstens Dannevirke]. Se trataba de la muy atinada aportación oficial de H. C. Andersen al rearme nacional en conexión con la Guerra de los Tres Años. La obra se representó a modo de preludio durante el centenario del Teatro Real el 18 de diciembre de 1848. Pero Andersen también recibió ayuda externa. Y, por primera vez, sin tener que mover un solo dedo.

El recién construido parque de atracciones de invierno, Casino, que había quebrado en julio de 1848 y había sido transformado en teatro, había abierto sus puertas el 26 de diciembre de ese mismo año. El 31 de diciembre, la dirección del teatro decidió poner de nuevo en escena Una comedia al aire libre de Andersen. De inmediato, Andersen se convirtió en el dramaturgo del Casino y en los siguientes diez años representó ahí nueve obras, si contamos la última pieza, En Langebro [Paa Langebro] de 1864. A estas piezas debemos añadir cuatro reestrenos de obras anteriores a la apertura del Casino. Además de Una comedia al aire libre, se volvieron a representar El árbol en el peral (1852), El hombre invisible de Sprogø (1855) y La flor de la felicidad (1858).

El 4 de noviembre de 1849, Andersen le escribe a su editor alemán, Carl B. Lorck: "Yo deseaba hacer todo lo posible para que el Casino se convirtiera en un teatro popular y para que gente de todas las clases pudiera asistir a él”. ${ }^{75}$ En otras palabras: el elemento popular que era rechazado e incomprendido por el buen gusto de Heiberg en el Teatro Real, aquí tendría por fin el reconocimiento que siempre ha merecido. El 13 de octubre le

75 "Andersen til Lorck, 4. november 1849 [Andersen a Lorck, 4 de noviembre de 1849]”, en H. C. Andersen Breve til Carl B. Lorck [Cartas de H. C. Andersen a Carl B. Lorck], ed. por H. Topsøe-Jensen, Odense: Odense Bys Museer, 1969, p. 206. 
escribió a Henriette Wulff con relación a la adaptación de Der Sonnwendhof de Mosenthal: "la obra tiene su sitio en nuestro 'Teatro Real', pero no quiero tener nada que ver con ellos; le daré la pieza al Casino". ${ }^{76}$

H. C. Andersen corrió con buena suerte y apostó de forma consciente por el elemento popular, entretenido, cómico y ligero; y por el papel central de la música. Se trataba, en resumidas cuentas, de algo por lo que sentía afición desde hace mucho y que había practicado con suerte diversa. Al parecer, había llegado el momento para el estilo propiamente anderseniano, con sus abundantes números musicales y episodios jocosos. Ahora era libre para escribir y adaptar lo que quisiera y pudiera.

Cinco de las nuevas obras eran adaptaciones bien logradas de éxitos de la escena europea que el cosmopolita y perspicaz Andersen sacó adelante con mano segura. En cada caso, indicaba escrupulosamente cuál había sido el original. Además de En Langebro, "Basada en la obra de Musæus y Kotzebue", está Una noche en Roskilde [En Nat i Roeskilde, 1849], "Adaptación de 'Une chambre à deux lits' de Warin y Lefevre", la muy exitosa Más que las perlas y el oro [Meer end Perler og Guld, 1849], "Basada en F. Raimund y 'Las mil y una noches'”, Una historia de aldea [En Landsbybistorie, 1855], basada en "Der Sonnwendhof" de S. H. Mosenthal, y A la luz de la luna. Escenas alpinas vistas desde los montes tiroleses [I Maaneskin. Alpescener fra de tyrolske Bjerge, 1855], "Basada en "Sletzti Fensterln' de Kobell y Seidl". En muchos casos, Andersen insertó canciones compuestas específicamente para la ocasión. Con su gran talento musical, era un maestro utilizando recursos auditivos.

De sus producciones originales, resultan menos interesantes esas dos piezas ligeras que llevan el mismo título, Introducción al carnaval [Indledning til Carnevalet] (en el Casino), representadas en 1853 y 1854 respectivamente. Las obras principales del "periodo Casino" son las dos comedias musicales de fantasía, Ole Lukøje de 1850 y Mamá Saúco [Hyldemoer] de 1851; ambas piezas siguen el mismo patrón de la comedia de fantasía Más que las perlas y el oro, la cual había tenido un éxito arrollador. Las dos obras tuvieron un recepción parecida, alcanzando respectivamente 66 y 60 representaciones en total. Es interesante observar que la tónica es muy diferente a la de Ahasverus. El péndulo se mueve hacia el extremo contrario de la duda. Ambas obras se basan en figuras tomadas de sus cuentos de hadas, "Ole Lukøje” de 1842 y "Mamá Saúco” de 1845, aunque las historias son nuevas.

76 "Andersen til Wulff, 13. okt. 1854 [Andersen a Wulff, 13 de octubre de 1854]", en H. C. Andersen og Henriette Wulff, en Brevveksling, vol. 2, p. 175. 
Ole Lukøje tiene muchos personajes y su trama es compleja. Sin embargo, su moraleja es simple: el dinero no lo es todo. La pieza inicia con la afirmación del ropavejero y solterón Blake, según la cual el amor siempre está motivado por consideraciones económicas. La intriga se desarrolla alrededor de esa declaración. En el medio se encuentra, como era la costumbre, una pobre pareja de enamorados: María y el deshollinador Christian. Este afirma confiado: "Salud y, encima de eso, buen humor / Tales son los mejores tesoros que se pueden tener" ${ }^{77}$ Pero el misterioso Blake es el diablo mismo; Christian queda cautivado por sus palabras y cambia de opinión. No obstante, mientras que el diablo anda suelto, aparece Ole Lukøje y hace que, en sueños, Christian ponga a prueba sus nuevas creencias. En su sueño, Christian tiene tres deseos. El cándido Christian empieza por pedir anguilas hervidas y chocolate; después, mucho dinero. Naturalmente, la buena vida que se da termina saliendo mal a causa de una intrincada operación con muchas cuentas. En resumen, y como era de esperarse, Christian pierde su dicha y a sí mismo. Al final, se encuentra con el hermano de Ole Lukøje, La Muerte, quien le dice la verdad: “Tu corazón sepultado está / Bajo una corriente de oro. Muerto está". ${ }^{78}$

Entonces Christian utiliza su tercer deseo para librarse de la maldición de las riquezas y despierta del sueño. La pieza concluye con su declaración edificante y su agradecimiento a sus maestros. Y con un homenaje a la frugalidad:

¡Ole Lukøje es mi amigo y su hermano también lo será cuando lo encuentre en el gran renacimiento, en mi segunda morada, ahí donde miradas dulces nos saludan! ¡Hurra! ¡Qué placer es vivir! ¡También dichosa es la muerte! ¡Creer en el mundo y en Nuestro Señor! Muchas gracias, pequeño Ole Lukøje.

\section{LOS TRES}

La frugalidad

Nos da paz en el alma,

Y donde hay paz,

Hay vida

Y felicidad. ${ }^{79}$

${ }^{77}$ H. C. Andersen, “Ole Lukøje”, en H.C. Andersens samlede værker 1-18, ed. por Klaus P. Mortensen, Copenhague: Det Danske Sprog- og Litteraturselskab, 2003-2077, vol. 13 , p. 18 .

${ }^{78}$ Andersen, "Ole Lukøje”, p. 82.

${ }^{79}$ Andersen, "Ole Lukøje”, p. 87. 
Esta optimista y sencilla lección de vida — con la cual, al parecer, chicos y grandes podían sentirse identificados- vuelve a aparecer en Mamá Saúco, una adaptación divertida del antiguo mito griego del aedo Orfeo, quien desciende al inframundo en busca de su difunta y amada esposa, Eurídice. Pero en su afán, olvida la prohibición según la cual no podía mirarla hasta no haber salido del infierno, razón por la cual debe abandonarla. Las cosas no salen tan mal en la versión de Andersen. Cuando el espíritu de la tierra, bajo la forma de un topo, secuestra a María, la amada del aprendiz de barbero Peter e hija de su maestro, y la hace beber de la fuente del olvido, Mamá Saúco, el hada del saúco y defensora del amor, acude en su auxilio. En el pequeño mito de Andersen, el amor no es algo que aparece de forma repentina, sino un sentimiento cultivado por largo tiempo del que uno se hace consciente de manera inesperada. Esta toma de consciencia depende de la capacidad para recordar. El amor de Peter por María - y el de María por Peter - se hace manifiesto cuando los dos recuerdan su vida en común cuando eran niños. Y lo que los hace recordar es precisamente el saúco bajo el cual jugaban durante su infancia. Mamá Saúco describe así el aroma de sus ramas:

Antiguos recuerdos ahí viven

Y las memorias queridas de los corazones.

Se trata de un tesoro tan magnífico

Que el poder tiene de atar y desatar. ${ }^{80}$

Sin la capacidad para el recuerdo, el ser humano no es más que una cáscara vacía, lo mismo que María después de haber bebido de la fuente del olvido:

¡Un sueño vacío y sosegado equivale a no ser!

Vivir, en cambio, es un rico tesoro,

Un tesoro de recuerdos queridos y preciosos,

Incluso de la triste y larga noche. ${ }^{81}$

Así, los dos personajes fantásticos, Ole Lukøje y Mamá Saúco, encarnan las capacidades que el ser humano debe poseer para eludir el vacío del desasosiego y el desarraigo: la capacidad de recordar, que permite afianzarse a la felicidad, y la capacidad de prever las consecuencias de alejarse de tal

${ }^{80}$ H. C. Andersen, "Hyldemoer”, en H.C. Andersens samlede værker 1-18, ed. por Klaus P. Mortensen, Copenhague: Det Danske Sprog- og Litteraturselskab, 2003-2077, vol. 13, p. 123.

${ }^{81}$ Andersen, "Hyldemoer", p. 125. 
estado de felicidad. Fuera de este estado original y armónico, el amor se convierte en un desierto, como sucede en el cuento "La reina de las nieves [Sneedronningen, 1845]". De esta manera, las comedias —al igual que una larga serie de cuentos de hadas - se alinean en contra de la duda y la desesperación, conjurando aquello que atormentaba a figuras como Inés y Ahasverus.

En este sentido, es sorprendente que las comedias hayan invertido todo su potencial para la fantasía y su vigor lingüístico en estas formas fascinantes de perdición. Aunque es verdad que son condenadas, ocupan un puesto principal en las dos piezas. Tal vez el fundamento de la producción de Andersen sea la incertidumbre, no el humor. Desde esa perspectiva, las sonrisas y las risas constituyen un auxilio para escapar de la fuerza gravitacional de la duda.

$X I V$

Con el reestreno en 1858 de La flor de la felicidad, obra que se anticipa a las lecciones de vida de Ole Lukøje y Mamá Saúco, comenzó el fin del periodo del Casino. El intento de devolverle la vida seis años después con el estreno de En Langebro, el 13 de marzo de 1864, no tuvo éxito. Mes y medio más tarde, H. C. Andersen regresó al Teatro Real con la comedia No es de cuna [Han er ikke født], en esta ocasión con una acogida relativamente benévola por parte de los críticos. El público, en cambio, se mostró indiferente. Las dos partes casi nunca estaban de acuerdo, lo cual era afortunado para el poeta. En esta nueva obra, se aborda nuevamente el tema de la nobleza de espíritu refiriéndose a la expresión "ser de cuna", es decir, ser de estirpe ilustre, y se confronta esto con el hecho biológico de que todo ser humano tiene literalmente un nacimiento. ${ }^{82}$

El ingenio y la malicia de La nueva babitación de la parturienta y El señor Rasmussen tienen una especie de renacimiento. La cultura superficial y el esnobismo con relación a los títulos vuelven a ser objeto de burla, pero es como si el ánimo del poeta se volviera más agresivo. El héroe de la obra, Frederik —un graduado distinguido y un representante ideal, aunque irascible, de la nobleza de espíritu—, critica con dureza la nobleza

${ }^{82}$ Nota del traductor. El título original en danés, Han er ikke født, puede traducirse literalmente como "él no ha nacido". En danés, sin embargo, la expresión también expresa el sentido de "no es de ilustre nacimiento" o, como lo hemos traducido nosotros, "no es de cuna”. De ahí el juego de palabras que utiliza Andersen. 
de nacimiento, con la cual, no obstante, tiene trato; por ejemplo, a través de la encantadora y bromista Elisabeth. Pero no solo termina enamorándose de ella, sino que se descubre también que Frederik, quien no sabe quiénes fueron sus padres, es hijo del libertino tío paterno de Elisabeth, el chambelán. Como sucede a menudo en los dramas y novelas de Andersen, la revelación del linaje desempeña un papel central. Al igual que Rafaela en La morisca, Frederik también es de noble cuna. Aquí, sin embargo, esto no conduce a un conflicto imposible, sino a una reconciliación. Con ligera ironía, Elisabeth se une a Frederik diciendo: "mi esposo no es de cuna". Si bien la nobleza de espíritu no surge del nacimiento, eso no significa que las dos cosas no puedan coexistir en una misma persona. Aquí la verdad sobre la nobleza de espíritu tiene algunos retoques.

En la comedia Cuando los españoles estuvieron aquí [Da Spanierne var her], Andersen retoma el tema de Despedidas y encuentros: la estancia de las tropas auxiliares españolas en Fionia durante las Guerras Napoleónicas. También en esta ocasión, se trata de una historia de amor en la que una muchacha danesa se enamora de un soldado español. Lo mismo que en La nueva babitación de la parturienta, El señor Rasmussen y No es de cuna, Andersen crea toda una galería de caracteres humorísticos alrededor de la historia amorosa, la cual termina por palidecer un poco en medio de tan colorida compañía. La pieza explora el tema de la esencia y las condiciones del amor verdadero. La caprichosa hija del canciller, bautizada con el sonoro nombre de Hermania, está comprometida con un noble cortesano, Carl, pero se enamora del fogoso Don Juan de Molina, quien trasluce el erotismo y exotismo de la cálida España. Este lleva siempre consigo la imagen de una hermosa señora. La imagen representa presuntamente a su difunta madre, a quien él ama con ardiente pasión. Al menos eso es lo que cree la romántica, mimada y egoísta Hermania; pero los espectadores sospechan lo peor. De esta manera, Hermania es seducida, aunque no solo por Don Juan. De forma sorpresiva, la imagen muestra, de hecho, a la madre. La seducción de Hermania, por su parte, ha sido el resultado de su carácter superficial y de su ciega terquedad, y debe pagar el precio cuando Don Juan se marcha con las tropas. Dolida por haber sido dejada atrás, se da cuenta de su error; mientras tanto, su amor por Don Juan se mantiene puro y lleno de esperanzas. El gentil y leal Carl, en cambio, termina con la fiel y humilde Anna. La moraleja, un poco insípida y previsible, es la siguiente: "La humildad es la base del amor". Así, no es sino hasta que la humildad se introduce en el corazón de la testaruda Hermania — la cual, a decir verdad, 
es la única figura interesante de la obra- que ella puede entrar a la tierra prometida del amor. Lo cual sucede justo antes de que el elemento didáctico le arrebate la batuta al drama.

Cuando los españoles estuvieron aquí, estrenada en el Teatro Real el 6 de abril de 1865 —inmediatamente después del cumpleaños sesenta del poeta-, fue la última representación teatral de Andersen. La recepción no fue demasiado entusiasta y ya no hubo más intentos en el género cómico. El pequeño drama de ocasión, En el carruaje del veturino [I Vetturirens Vogn], escrito en 1869, nunca llegó a la escena. En lo que podría llamarse el último y fugaz episodio como dramaturgo de Andersen entre 1864 y 1865 es preciso incluir también el libreto operístico El rey Saúl [Kong Saul]. La obra estaba lista en 1864, pero no fue representada e impresa completa sino hasta después de la muerte del poeta, en el volumen 31 de los Escritos reunidos en 1876.

En El rey Saúl volvemos al ámbito de la seriedad y la duda. Esta ópera es el único drama bíblico de Andersen. La pieza, de tensa composición, se basa en el rey Saúl, quien atenta en contra de la vida de David. Sin embargo, lo que Andersen intenta plasmar no son los sucesos dramáticos y brutales, sino los demonios internos. Para Saúl mismo su propia existencia es un enigma. De ser benévolo y magnánimo, se ha convertido en un déspota enfermizamente receloso, violento y lleno de odio que desafía incluso a Jehová y a su profeta, Samuel. Saúl señala que es como si una serpiente o un demonio maligno le oprimiera el corazón. Pero aunque se da una reconciliación y David se casa con la hija de Saúl, este no puede liberarse de la serpiente, cuyo poder crece al mismo ritmo que su desconfianza:

Hay en mí una oscuridad que oprime mi ánimo

(...)

Todo empieza y termina en nosotros mismos.

Esta certeza crece en mí:

Nadie existe en quien se pueda confiar plenamente. ${ }^{83}$

La figura de Saúl constituye una exploración acerca del poder humano y la psicología de la duda. Angustiada frente a la posibilidad de perder el poder, la omnipotencia se vuelca hacia la desconfianza total frente a todo y todos. Esto significa, en sus consecuencias radicales, que el poderoso no puede

${ }^{83}$ H. C. Andersen, "Kong Saul”, en H.C. Andersens samlede værker 1-18, ed. por Klaus P. Mortensen, Copenhague: Det Danske Sprog- og Litteraturselskab, 2003-2077, vol. 13, p. 587. 
ni siquiera confiar en sí mismo. Saúl termina por convencerse de que su propia persona está poseída por fuerzas que él no puede dominar y que son conducidas por la voluntad maligna de alguien más:

Has pactado,

Bajo misteriosas condiciones,

Con un demonio que desaconseja

Y vacila dentro de mí.

Que practica el mal

Y me tiene encadenado. ${ }^{84}$

Cuando entonces Saúl pierde la cordura e intenta matar a David para, de esa manera, librarse de la posesión, esta orgía de violencia termina, como era de esperarse, en la autodestrucción. Pues en su locura, acaba, en cierto sentido, viendo con claridad: el mal que lleva dentro y del que él busca liberarse de forma externa, en realidad solo puede destruirse dirigiendo la espada en contra de sí mismo.

Mientras que Ahasverus se redime lentamente de los elementos destructivos, Andersen concluye su carrera dramática — quizá de forma imprevista- describiendo a un personaje escéptico que se precipita al vacío. Dentro de la indeterminación potencial de la duda se atisba la solución total: la locura, la destrucción. El rey Saúl proyecta una sombra oscura sobre la ligereza y jocosidad de las comedias y vodeviles. Y la duda pronuncia la última y terrible palabra.

\section{Bibliografía}

Andersen, Hans Christian, Breve fra Hans Christian Andersen, ed. por C. A. Bille y Nikolaj Bøgh, vol. 2, Copenhague: Reitzel, 1878.

H. C. Andersen Breve til Carl B. Lorck, ed. por H. Topsøe-Jensen, Odense: Odense Bys Museer, 1969.

H. C. Andersens Brevveksling med Edvard og Henriette Collin, vols. 1-6, Copenhague: Levin \& Munskgaards Forlag, 1933-1937.

H. C. Andersen og Henriette Wulff, en Brevveksling, vols. 1-3, Odense: Flensted Forlag, 1959.

${ }^{84}$ Andersen, “Kong Saul”, p. 588. 
- H.C. Andersens samlede værker, vols. 1-18, ed. por Klaus P. Mortensen, Copenhague: Det Danske Sprog- og Litteraturselskab, 2003-2077.

“Andersen til Christian Voigt, 26. Juni. 1833”, en Anderseniana, vol. 1, no. 2, 1948.

Heiberg, Johan Ludvig, Breve og Aktstykker vedrørende Johan Ludvig Heiberg, vols. 1-5, ed. por Martin Borup, Copenhague: Gyldendal, 1948.

Heiberg, Johan Ludvig (ed.), Kjøbenhavns flyvende Post, no. 72, 28 de marzo de 1845 .

Ørsted, Hans Christian, Breve fra og til H. C. Ørsted, vols. 1-2, Copenhague: Th. Linds Forlag, 1870. 